\title{
Mechanistic Exploitation of a Self-Repairing, Blocked Proton Transfer Pathway in an $\mathrm{O}_{2}$-Tolerant [NiFe]-Hydrogenase
}

Rhiannon M. Evans, ${ }^{\dagger}$ Philip A. Ash, ${ }^{\dagger}$ Stephen E. Beaton, ${ }^{\dagger}$ Emily J. Brooke, ${ }^{\dagger}$ Kylie A. Vincent, ${ }^{\dagger}$

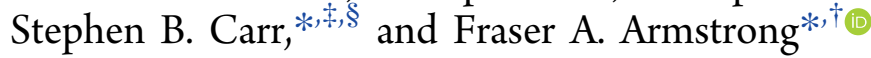

${ }^{\dagger}$ Department of Chemistry, University of Oxford, Oxford OX1 3QR, United Kingdom

${ }^{\ddagger}$ Research Complex at Harwell, Rutherford Appleton Laboratory, Harwell, Didcot OX11 0QX, United Kingdom

${ }^{\S}$ Department of Biochemistry, University of Oxford, Oxford OX1 3QU, United Kingdom

\section{Supporting Information}

\begin{abstract}
Catalytic long-range proton transfer in [NiFe]hydrogenases has long been associated with a highly conserved glutamate (E) situated within $4 \AA$ of the active site. Substituting for glutamine $(\mathrm{Q})$ in the $\mathrm{O}_{2}$-tolerant $[\mathrm{NiFe}]$ hydrogenase-1 from Escherichia coli produces a variant (E28Q) with unique properties that have been investigated using protein film electrochemistry, protein film infrared electrochemistry, and X-ray crystallography. At $\mathrm{pH} 7$ and moderate potential, E28Q displays approximately $1 \%$ of the activity of the native enzyme, high enough to allow detailed infrared measurements under steady-state conditions. Atomiclevel crystal structures reveal partial displacement of the amide side chain by a hydroxide ion, the occupancy of which increases with $\mathrm{pH}$ or under oxidizing conditions supporting formation of the superoxidized state of the unusual proximal [4Fe-3S] cluster located nearby. Under these special conditions, the essential exit pathway for at least one of the $\mathrm{H}^{+}$ions produced by $\mathrm{H}_{2}$ oxidation, and assumed to be blocked in the E28Q variant, is partially repaired. During steady-state $\mathrm{H}_{2}$ oxidation at neutral $\mathrm{pH}$ (i.e., when the barrier to $\mathrm{H}^{+}$exit via Q28 is almost totally closed), the catalytic cycle is dominated by the reduced states " $\mathrm{Ni}_{\mathrm{a}}-\mathrm{R}^{\text {" and } ~} \mathrm{Ni}_{\mathrm{a}}-\mathrm{C}$ ", even under highly oxidizing conditions. Hence, E28 is not involved in the initial activation/deprotonation of $\mathrm{H}_{2}$, but facilitates $\mathrm{H}^{+}$exit later in the catalytic cycle to regenerate the initial oxidized active state, assumed to be $\mathrm{Ni}_{\mathrm{a}}$-SI. Accordingly, the oxidized inactive resting state, "Ni-B", is not produced by $\mathrm{E} 28 \mathrm{Q}$ in the presence of $\mathrm{H}_{2}$ at high potential because $\mathrm{Ni}_{\mathrm{a}}$-SI (the precursor for Ni-B) cannot accumulate. The results have important implications for understanding the catalytic mechanism of [NiFe]-hydrogenases and the control of longrange proton-coupled electron transfer in hydrogenases and other enzymes.
\end{abstract}

\section{INTRODUCTION}

The cycling of hydrogen $\left(\mathrm{H}_{2}\right)$ by microorganisms has strong connections to biotechnology, energy and health. ${ }^{1-3}$ The metalloenzymes known as hydrogenases offer a paradigm for fast, efficient and reversible ${ }^{4}$ hydrogen electrocatalysis requiring only a minimal overpotential in either direction, and set a very high standard for designing catalysts based on abundant, nonplatinum metals. $^{5-7}$

Molecular $\mathrm{H}_{2}$ activation is the simplest of all proton-coupled electron-transfer reactions. Hydrogenases operate in neutral water and use a heterolytic mechanism $\left(\mathrm{H}_{2} \rightleftharpoons \mathrm{H}^{+}+\mathrm{H}^{-} \rightleftharpoons\right.$ $\left.2 \mathrm{H}^{+}+2 \mathrm{e}^{-}\right)^{8}$ so it is highly significant that their active sites are deeply buried and almost completely sealed from solvent. In fact, they are remarkable among all enzymes in that $\mathrm{H}_{2}$, the smallest of molecules, is solely formed from (or converted into) four quantum particles that must hop and tunnel through the protein. The specific routes taken by protons and electrons between solvent and active site reflect the fact that the characteristic tunneling distance for a proton is about 45 times shorter than for an electron; ${ }^{9}$ hence a proton pathway requires closely spaced donor-acceptor groups (mobile side chains and water molecules) whereas electron-transfer sites are typically 10-14 $\AA$ apart. ${ }^{10}$ Neutral gas molecules, whether substrates or inhibitors, are expected to enter and leave the active site via preferred hydrophobic tunnels. ${ }^{11-13}$ Additionally, and especially for the special ' $\mathrm{O}_{2}$-tolerant' class of $[\mathrm{NiFe}]$-hydrogenases that can function continuously in the presence of $\mathrm{O}_{2}{ }^{14}$ (and thus act as hydrogen oxidases ${ }^{15,16}$ ) hydrophilic pathways must exist to ensure rapid escape of water molecules following $\mathrm{O}_{2}$ attack. $^{12,17,18}$

The Escherichia coli membrane-bound [ $\mathrm{NiFe}]$-hydrogenase $(\mathrm{MBH})$ "Hyd-1" is $\mathrm{O}_{2}$-tolerant with a strong bias toward hydrogen oxidation at neutral $\mathrm{pH}$, whereas the $\mathrm{O}_{2}$-sensitive MBH "Hyd-2" from E. coli operates in both directions. ${ }^{19,20}$ The active site, housed in the large subunit of the

Received: May 10, 2018

Published: August 2, 2018 
(A)

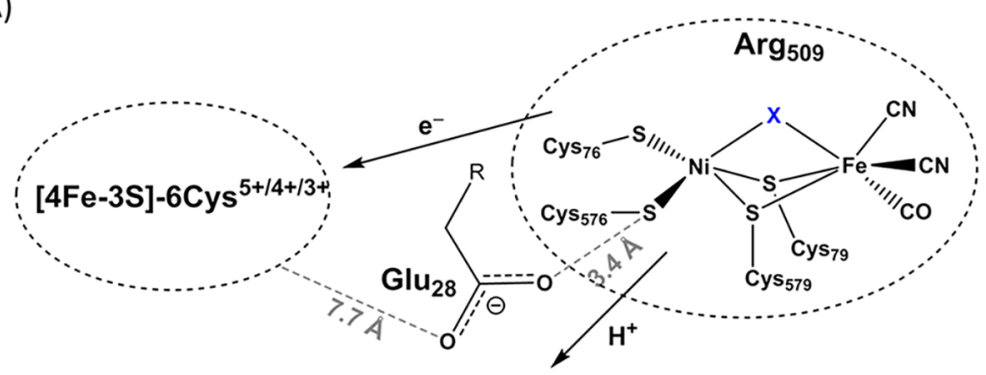

(B)

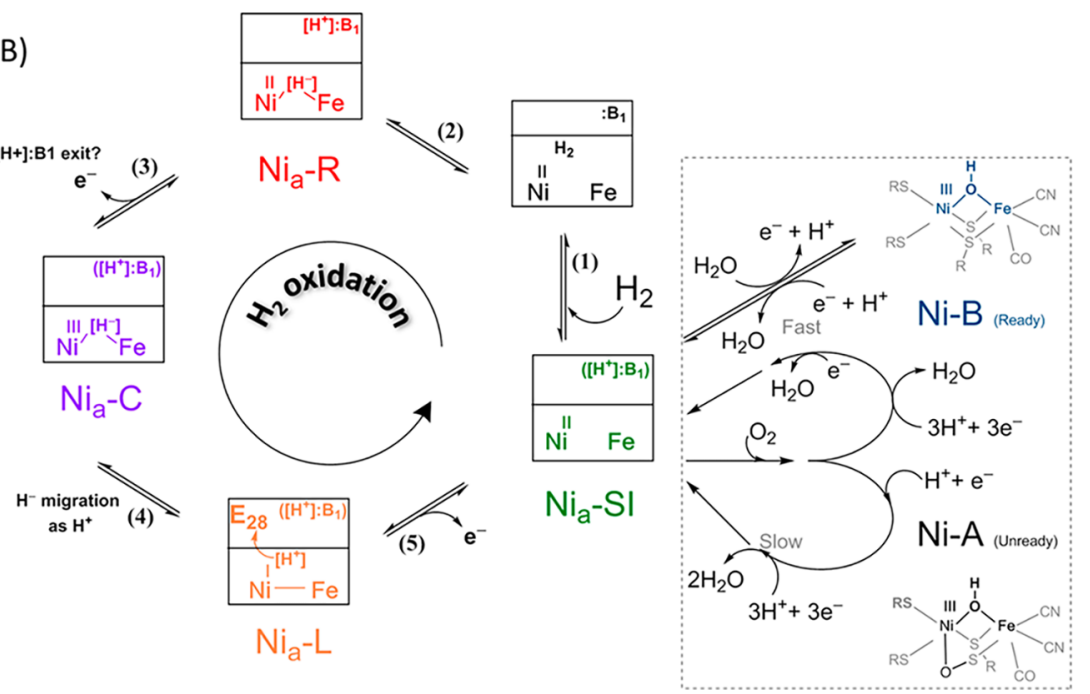

Figure 1. Schematic representation of the orientation of E28 in native Hyd-1 (A), in which the noncoordinating residues E28 and R509 so far established to be essential for catalysis are included. Distances (gray) between the carbonyl-O atoms of E28 and the nearest $\mathrm{Fe}$ atom of the [4Fe$3 \mathrm{~S}]-6_{\mathrm{Cys}}$ proximal $\mathrm{Fe}-\mathrm{S}$ cluster and the cysteine-S of Ni-coordinated cysteine 576 are shown (pdb.5A4M). The atom which bridges the Ni and Fe is denoted as ' $\mathrm{X}$ ' to represent the varied identification of the ligand depending on the oxidation state (as shown in the catalytic cycle, B) and presence of various inhibitory small molecules. (B) In the catalytic cycle, the catalytically active (a) states are denoted "Ni" whereas the inactive oxidized states generated anaerobically at high potential (Ni-B) or upon the binding of oxygen (Ni-B or Ni-A depending on the number of electrons immediately available to reduce the attacking $\mathrm{O}_{2}$, see refs $\left.{ }^{65,69}\right)$ are shown in the gray box. Each catalytic state is shown in a black box: the lower half represents the current consensus on the minimal $[\mathrm{Ni}, \mathrm{Fe}, \mathrm{H}]$ unit of the active site, including oxidation states and bonding, the upper half represents the proton acceptor(s) not associated with the minimal unit. During $\mathrm{H}_{2}$ oxidation, $\mathrm{H}_{2}$ binds to the $\mathrm{Ni}_{\mathrm{a}}$-SI state (1), heterolytic activation of $\mathrm{H}_{2}$ requires deprotonation by a nearby base ( $\left(: \mathrm{B}_{1}\right.$, the identity of which is still under debate $\left.{ }^{17,23,27,70,71}\right)$ forming $\mathrm{Ni}_{\mathrm{a}}-\mathrm{R}$ which has a bridging hydride (2). ${ }^{71}$ The subsequent stage of the catalytic cycle in which the proton on $B_{1}$ leaves the active site is unknown at present (so we denote the protonated base in parentheses $\left.\left(\left[\mathrm{H}^{+}\right]: \mathrm{B}_{1}\right)\right)$, though $\mathrm{B}_{1}$ must be deprotonated prior to stage 2 in order for the next molecule of $\mathrm{H}_{2}$ to be activated. Following electron transfer $\mathrm{Ni}_{\mathrm{a}}-\mathrm{C}$ is formed (3). The bridging hydride of $\mathrm{Ni}_{\mathrm{a}}-\mathrm{C}$ migrates as a proton, the initial proton acceptor proposed to be a terminal cysteine thiolate (4), ${ }^{27,70}$ and the resulting $\mathrm{Ni}_{\mathrm{a}}-\mathrm{L}$ state is proposed to contain a dative metal-metal bond. ${ }^{72}$ Finally, a second electron is transferred to the proximal $\mathrm{Fe}-\mathrm{S}$ cluster to form $\mathrm{Ni}_{\mathrm{a}}$-SI (5).

heterodimeric protein complex, has similar architecture in all cases, the essential features being summarized in Figure 1A. ${ }^{17,21,22}$ The $\mathrm{Ni}$ and $\mathrm{Fe}$ atoms are anchored to the protein by four cysteine thiolates, two of which are bridging ligands while the other two are terminal to the $\mathrm{Ni}$ : the $\mathrm{Fe}$ atom is further ligated by one $\mathrm{CO}$ and two $\mathrm{CN}^{-}$ligands. Depending on the stage of the minimal catalytic cycle shown in Figure 1B, a fifth ligand to the $\mathrm{Ni}$ may be present, in a bridging position between the $\mathrm{Ni}$ and $\mathrm{Fe}$ atoms (the $\mathrm{Fe}$ remains low-spin $\mathrm{Fe}^{\mathrm{II}}$ throughout). Immediately above the metal atoms lies the outer coordination shell "canopy" that includes the guanidinium group of arginine 509, recently demonstrated to be essential for fast $\mathrm{H}_{2}$ oxidation by Hyd-1. ${ }^{17,23}$

Whereas the detailed mechanism by which the $\mathrm{H}-\mathrm{H}$ bond is formed or cleaved remains to be resolved, much more is known about the pathways of electrons to and from the buried active site. In MBHs, electrons are transferred via a chain of $\mathrm{Fe}-\mathrm{S}$ clusters housed in the small subunit that connects the active site to the biological membrane or redox partner protein. The $\mathrm{Fe}-\mathrm{S}$ chain comprises three $\mathrm{Fe}-\mathrm{S}$ clusters termed "proximal", "medial" and "distal" according to their distance from the active site. In contrast to this clearly marked pathway for electrons, our insight into long-range proton transfer owes much to the seminal work of Dementin and co-workers ${ }^{24}$ who showed that a highly conserved glutamate ${ }^{23}$ (E28 in E. coli Hyd-1, Figure 1A) located at the interface of the large and small subunits, and in direct contact with an extensive network of water molecules (see later and Figure S1) is critical for proton transport from the active site during $\mathrm{H}_{2}$ oxidation. Mutation of E28 to glutamine (carboxylate-to-amide) in the [NiFe]-hydrogenase from Desulfovibrio fructosovorans resulted in a protein that could cleave $\mathrm{H}_{2}$ within the active site, but was unable to exchange protons with solvent, resulting in $>99.9 \%$ lowering of the $\mathrm{H}_{2}$ oxidation rate. No electrochemical or structural data were presented. There has since been compelling support for a key role for this residue in proton 
transfer (most likely via a swinging arm mechanism ${ }^{25}$ ) with substitutions for glutamine greatly attenuating steady-state turnover rates. The most profound result was reported by Adamson et al., ${ }^{26}$ who concluded (based on studies at $\mathrm{pH} 6$ and below) that the E28Q variant of Hyd-1 had no discernible catalytic activity. Other studies have shown partial decreases in activity, ranging from approximately $19 \%(\mathrm{pH} 7.5)$ for the $\mathrm{NADP}^{+}$-linked $^{14}$ soluble hydrogenase I (SHI) from Pyrococcus furiosus $^{27}$ to approximately $50 \%(\mathrm{pH} 7)$ in the $\mathrm{MBH}$ "Hyn" from Thiocapsa roseopersicina $\mathrm{BBS}^{28}$ It is important to note that the active sites of $[\mathrm{NiFe}]$-hydrogenases contain many ordered water molecules $\left(\mathrm{H}_{2} \mathrm{O}\right.$ or $\left.\mathrm{OH}^{-}\right)$the positions of which are highly conserved: ${ }^{17}$ it is very likely that $\mathrm{H}^{+}$can transfer easily within the active site itself.

Protein film electrochemistry (PFE) allows the $\mathrm{H}_{2}$ oxidation or $\mathrm{H}^{+}$reduction reactions of an immobilized hydrogenase to be driven and monitored in either direction depending on the electrode potential applied. ${ }^{29,30}$ Enzymes can be investigated under challenging conditions such as highly oxidizing potentials and even extremes of $\mathrm{pH}$. The resulting effects on catalytic activity, measured directly as current, are immediately evident. Even enzymes with very little activity can be studied using a high-surface area working electrode coated with multiwalled carbon nanotubes (MWNT). ${ }^{17,23,31,32}$ Protein film infrared (IR) electrochemistry (PFIRE) utilizes the same principles as PFE, the important addition being that the status of the active site is monitored during turnover or under equilibrium (non-turnover) conditions, via the stretching frequencies of the $\mathrm{CO}$ and $\mathrm{CN}^{-}$ligands of the active site $\mathrm{Fe}$ atom. ${ }^{33,34}$

The apparent total inactivity of the E28Q variant of Hyd-1 observed previously ${ }^{26}$ suggested strongly that this enzyme depends entirely on a single route for entry and exit of at least one of the two protons produced at an "encapsulated" $\mathrm{H}_{2}$ activation site. In this paper we show that the residual low activity is sufficient to allow highly informative experiments that address the distribution of catalytic intermediates under steady-state $\mathrm{H}_{2}$ oxidation. We have revisited the E28Q variant (and equivalent variant in Hyd-2, E14Q) along with additional mutations in Hyd-1 in a series of studies involving X-ray structure determination, PFE and PFIRE, the latter reporting on the catalytic steps within the active site (Figure 1B) that are dependent on having an efficient escape route for protons via E28. Under steady state conditions, "stages" of the catalytic cycle (Figure 1B) that require exit of $\mathrm{H}^{+}$via E28 should be restricted thereby allowing the preceding state or states to dominate the spectra. An unexpected result is that the $\mathrm{H}_{2}$ oxidation activity increases greatly at high $\mathrm{pH}$ and oxidizing conditions, the origin of this enhancement being revealed in the crystal structures. The results have important significance for understanding the mechanism of enzymatic $\mathrm{H}_{2}$ oxidation and how catalysis is linked to long-range proton transfer.

\section{EXPERIMENTAL SECTION}

2.1. Molecular Biology and Enzyme Production. Variants of Hyd-1 were produced following standard molecular biology procedures as outlined in the Supporting Information. ${ }^{17,23}$ All Hyd1 strains (Table S1) were used for chromosomal expression of the Hyd-1 enzymes, and protein was purified from the cell membrane via detergent solubilization and Ni-affinity chromatography, as previously described. ${ }^{19}$ For structural studies, additional size-exclusion and hydroxyapatite chromatography was performed. ${ }^{17,22,23}$ The Hyd-2 enzymes were purified from the cell cytoplasm, following overproduction of the $\mathrm{HybO}$ ( $\mathrm{Fe}-\mathrm{S}$ cluster-containing) subunit, as recently reported. ${ }^{21}$ The resulting native Hyd-2, previously termed "Hyd-2-NOP", (native, "overproduced"), is simply denoted "Hyd-2". For the Hyd-2 variant E14Q, strain HJ001-hyp hybC was mutated as outlined in Table S1. Enzymes Hyd-2 and E14Q were purified by Niaffinity chromatography, and for subsequent structural studies underwent additional size-exclusion chromatography. ${ }^{21}$

2.2. Steady State Solution Assays. Turnover rates for $\mathrm{H}_{2}$ oxidation were measured by anaerobic steady-state solution assays in an $\mathrm{N}_{2}$-filled glovebox (Belle Technologies, $\mathrm{O}_{2}<2$ ppm). ${ }^{17,23,21}$ Data were collected for Hyd-1 enzymes using methylene blue (SigmaAldrich) and for Hyd-2 enzymes using benzyl viologen (Fluka) at 25 ${ }^{\circ} \mathrm{C}$, using an Ocean Optics S2000 fiber optic spectrometer controlled with OOIBase32 software (Ocean Optics, Inc.). The extinction coefficients used were $22.4 \mathrm{mM}^{-1} \mathrm{~cm}^{-1}$ (at $600 \mathrm{~nm}$, methylene blue) ${ }^{35}$ and $8.4 \mathrm{mM}^{-1} \mathrm{~cm}^{-1}$ (at $604 \mathrm{~nm}$, benzyl viologen). ${ }^{36}$

Enzyme solutions were reductively activated for 24-48 h (Hyd-1 enzymes) or 12-24 h (Hyd-2 enzymes) under an atmosphere of $100 \% \mathrm{H}_{2}$ at room temperature $\left(21^{\circ} \mathrm{C}\right)$. $\mathrm{A} \mathrm{H}_{2}$-saturated solution (i.e., $1 \mathrm{~mL}, 25 \mu \mathrm{M}$ methylene blue, or $2 \mathrm{mM}$ benzyl viologen, both in 0.10 M potassium phosphate, $0.10 \mathrm{M} \mathrm{NaCl}, \mathrm{pH} 6-10.8$, titrated at room temperature) was monitored for $\sim 60 \mathrm{~s}$ in a sealed cuvette containing a micro magnetic stirrer ball. Enzyme solution $(5 \mu \mathrm{L})$ was then injected using a Hamilton syringe, typically delivering $1 \mathrm{ng}-10 \mu \mathrm{g}$ depending on the enzyme in question.

2.3. Protein Film Electrochemistry and Protein Film Infrared Electrochemistry. Both PFE and PFIRE experiments were carried out using a potentiostat (PGSTAT 20, or PGSTAT $128 \mathrm{~N}$, Metrohm Autolab) controlled by Nova software (EcoChemie). A three-electrode system was used in each case, comprising a Pt wire counter, a saturated calomel reference and a working electrode. For PFE the working electrode consisted of a pyrolytic graphite "edge" (PGE, Momentive Performance Materials Ltd.) electrode, constructed in-house. $^{29}$ For PFIRE, the working electrode was a high surface area carbon black (BP2000, Cabot Corporation) particle electrode. ${ }^{33,34}$ All potentials are quoted against the standard hydrogen electrode using the correction $E_{\mathrm{SHE}}=E_{\mathrm{SCE}}+241 \mathrm{mV}$, at $25^{\circ} \mathrm{C}$. ${ }^{37}$

Unless otherwise stated, all experiments were carried out using a mixed buffer solution, ${ }^{29}$ prepared using ultrapure water (Millipore, 18 $\mathrm{M} \Omega \mathrm{cm}$ ) and titrated to the desired $\mathrm{pH}$ at the temperature of the experiment to be performed: for PFIRE this was always $\mathrm{pH} 7.0$ at 27 ${ }^{\circ} \mathrm{C}$. All gases were of high purity (BOC gases) and precise mixtures were obtained using mass flow controllers (Sierra Instruments or Brooks). Protein film electrochemistry experiments were carried out using a gastight, water-jacketed glass electrochemical cell ${ }^{29}$ housed in an anaerobic glovebox (Belle Technologies, or MBraun, $\mathrm{O}_{2}<2 \mathrm{ppm}$ ). To avoid mass transport limitations, the working electrode was rotated at high speeds $(1000-3000 \mathrm{rpm})$ as the experiment dictated. Protein film infrared electrochemistry was carried out using a spectroelectrochemical flow cell as described previously, ${ }^{33,34}$ and mass transport limitation was avoided by using a high solution flow rate $(\geq 60 \mathrm{~mL} / \mathrm{min})$ through the PFIRE cell via a peristaltic pump (Whatman, 120U/D1). Infrared spectra were recorded using a custom-modified attenuated total reflectance (ATR) accessory (PIKE Technologies, GladiATR) in a Bruker Vertex 80 FTIR spectrometer, equipped with a liquid $\mathrm{N}_{2}$-cooled mercury cadmium telluride detector, housed in a dry, anaerobic glovebox (Glove Box Technology Ltd., $<2$ ppm of $\mathrm{O}_{2},<85{ }^{\circ} \mathrm{C}$ dew point). Spectra were recorded using OPUS software, as an average of 256 interferograms $(20 \mathrm{kHz})$ at 2 $\mathrm{cm}^{-1}$ resolution, and processed by OriginPro 2017 (OriginLab).

For PFE experiments, in the first instance, protein films were prepared for all enzymes using a PGE working electrode of geometric surface area $0.03-0.05 \mathrm{~cm}^{2}$ : the electrode surface was abraded with P400 (3 M Hookit) sandpaper and rinsed with ultrapure water. Enzyme solution $(1-2 \mu \mathrm{L}$ at $10-500 \mu \mathrm{M})$ was continuously applied and reapplied via pipet to the electrode surface for $30 \mathrm{~s}$, then rinsed with ultrapure water to remove unadsorbed enzyme. To obtain a much higher electrode coverage and thus observe the catalytic $\mathrm{H}_{2}$ oxidation activity of low-activity Hyd-1 and Hyd-2 variants, a modified electrode e $^{17,23,31,32}$ was used: the PGE electrode was first coated with a dispersion $(32 \mu \mathrm{L})$ of multiwalled carbon nanotubes 
(MWNT, Sigma-Aldrich, outer diameter $\times$ length $=6-9 \mathrm{~nm} \times 5$ $\mu \mathrm{m}$ ), at a loading of $1 \mathrm{mg} / \mathrm{mL}$ in dimethylformamide (DMF, Acros Organics) and allowed to dry. A solution $(32 \mu \mathrm{L})$ of 1-pyrenebutyric acid (Sigma-Aldrich, $10 \mathrm{mM}$ in DMF) was then applied for $1 \mathrm{~h}$ before rinsing with ultrapure water. The carboxylic acid groups were activated with a solution (32 $\mu \mathrm{L})$ of 1-ethyl-3-(3-(dimethylamino)propyl) carbodiimide (EDC, Fluorochem, $0.4 \mathrm{M}$ in ultrapure water) and $n$-hydroxysulfosuccinimide (NHSS, Sigma-Aldrich, $0.1 \mathrm{M}$ in ultrapure water) for $45 \mathrm{~min}$. Electrodes were rinsed with ultrapure water and the enzyme solution $(10 \mu \mathrm{L}$ at $10-100 \mu \mathrm{M})$ was applied for $1 \mathrm{~h}$ at room temperature, followed by rinsing with ultrapure water. For PFE experiments, enzyme films were reductively activated under an electrochemical cell headspace of $100 \% \mathrm{H}_{2}$, with application of a reducing potential (typically $-0.66 \mathrm{~V}$ ). Progress was monitored by periodically returning to a $\mathrm{H}_{2}$ oxidation potential $(-0.2$ to $0 \mathrm{~V}$, depending on the enzyme) and monitoring the $\mathrm{H}_{2}$ oxidation current. Activation was deemed complete when there was no significant increase in current.

"Film loss" describes a general decrease in current over time and can reflect a number of changes in the enzyme film, for example, the physical desorption of the enzyme from the electrode, global and/or local unfolding of the enzyme or rearrangement of its orientation. Film loss is exponential and the degree to which it occurs depends on the history of the film. Counterintuitively, "film loss" effects have also been reported in cases where hydrogenases are covalently attached to an electrode surface, presumably due to enzyme instability under the experimental conditions and initial removal of physically adsorbed material. ${ }^{32,38,39}$ Film loss correction, where indicated, was achieved by always returning to a standard condition; for example, after exposure to a different $\mathrm{pH}$, the film was always re-exposed to $\mathrm{pH} 6.0$ and the decrease in current was monitored at each potential over time. Any film loss was then corrected for by fitting the measured current at $\mathrm{pH}$ 6 to an exponential decay function. ${ }^{29}$

A similar modification protocol was used to obtain high coverage enzyme films for PFIRE experiments (see Supporting Information). Enzyme-loaded particles were held under a $\mathrm{H}_{2}$ atmosphere (3 bar, 4 ${ }^{\circ} \mathrm{C}$ ) for 5 days to facilitate adsorption and simultaneous activation of the as-isolated enzyme. Before carrying out PFIRE measurements, the immobilized enzyme was activated further in the PFIRE cell by poising at a reducing potential $(-0.6 \mathrm{~V})$ under $100 \% \mathrm{H}_{2}$ for $12 \mathrm{~h}$. Periodically (every $2 \mathrm{~h}$ ) the atmosphere was switched to $100 \% \mathrm{Ar}$ to ensure complete removal of oxidized, inactive species formed during aerobic purification of the enzyme.

2.4. Crystal Structure Determinations. Aerobically purified ("as-isolated") enzymes were crystallized as described previously $^{17,21,22}$ at $\mathrm{pH} 5.9$ for E28Q (Table S4), $\mathrm{pH} 8.1$ for native Hyd-1, pH 5.9 for E28D (Table S5), and pH 5.9 for E14Q Hyd-2 (Table S6). Reduced samples were prepared using as-isolated enzyme at $\mathrm{pH} 5.9$ or 8.1, purged under an atmosphere of $100 \% \mathrm{H}_{2}$ in an anaerobic glovebox (Belle Technology Ltd., UK, $\mathrm{O}_{2}<2 \mathrm{ppm}$ ), at $5{ }^{\circ} \mathrm{C}$ for $40 \mathrm{~h}$ (E28Q) or $18 \mathrm{~h}$ (native Hyd-1), then crystallized as described previously ${ }^{17}$ at $23{ }^{\circ} \mathrm{C}$ (ambient glovebox temperature). Reduction of the E14Q variant by $\mathrm{H}_{2}$ was achieved by exposing an enzyme solution $(5 \mathrm{mg} / \mathrm{mL})$ to 4 bar $\mathrm{H}_{2}$ in an pressure vessel (Tinyclave Steel, Büchiglasuster) for $12 \mathrm{~h}$ at $4{ }^{\circ} \mathrm{C}$, then crystallized as described previously at $23{ }^{\circ} \mathrm{C}$ (ambient glovebox temperature). ${ }^{21}$ To obtain a structure at $\mathrm{pH} 10, \mathrm{H}_{2}$-reduced crystals of E28Q (grown at $\mathrm{pH}$ 8.1) were soaked for $2-3 \mathrm{~min}$ in a solution containing $100 \mathrm{mM}$ CAPS, pH 10.0, $150 \mathrm{mM} \mathrm{NaCl}, 200 \mathrm{mM} \mathrm{Li}_{2} \mathrm{SO}_{4}, 23 \%$ (w/v) PEG 3350 . All crystals were cryoprotected by adding glycerol $(15 \%, \mathrm{v} / \mathrm{v})$ and 2\% extra PEG 3350 to the crystallization buffer before flashcooling in liquid $\mathrm{N}_{2}$ in the glovebox. From this point on we will refer to the $\mathrm{pH}$ of the crystal structures as " 6 ", " 8 ", or " 10 ".

$\mathrm{X}$-ray diffraction data were collected at Diamond Light Source at beamlines I24 or I03 (at wavelength $=0.98 \AA$, Pilatus $36 \mathrm{M}$ detector), or beamline I04-1 (at wavelength $=0.92 \AA$, Pilatus $6 \mathrm{M}$ detector). Data reduction was performed with DIALS $^{40}$ and AIMLESS. ${ }^{41}$ Initial phase estimates were generated by performing rigid body refinement of the native Hyd-1 structure (pdb 5A4M) into the unit cell of the different variant Hyd-1 proteins using REFMAC. ${ }^{42}$
The same procedure was used for E14Q instead using the Hyd-2 structure (pdb 6EHQ). Twenty rounds of rigid-body refinement were performed with the data truncated to a maximum resolution of $6 \AA$, before carrying out a further 20 rounds with the data extended to the maximum resolution available. Models were manually adjusted with $\mathrm{COOT}^{43}$ followed by all-atom refinement using REFMAC, a process that was repeated until refinement converged. The degree of oxygenation of cysteine 79 in the as-isolated structure of E28Q was estimated as described previously. ${ }^{17}$

\section{RESULTS}

3.1. Enzyme Production. All Hyd-1 enzymes were produced to a similar yield $(\sim 0.2 \mathrm{mg} / \mathrm{L}$ media $)$ and were indistinguishable by denaturing electrophoresis (Figure S2A), each comprising proteolytically processed large (HyaB) and small (HyaA) subunits following Ni-affinity chromatography. Production of all Hyd-2 enzymes utilized the overproduction system described recently, ${ }^{21}$ raising the yield in-line with that of Hyd-1. The Hyd-2 enzymes were indistinguishable by denaturing electrophoresis (Figure S2B), both containing overproduced $\mathrm{HybO}$ small subunit, and processed HybC large subunit.

3.2. Characterization of E28 Variants by PFE and Discovery of Unusual Activities. Viewed with a normal PGE electrode at $\mathrm{pH} \mathrm{6,} \mathrm{the} \mathrm{E28Q} \mathrm{variant} \mathrm{of} \mathrm{Hyd-1} \mathrm{is} \mathrm{inactive}$ except for a marked increase in current above $+0.1 \mathrm{~V}$ (Figure S3). In contrast, using a modified electrode, ${ }^{17,23,31,32}$ the detailed $\mathrm{H}_{2}$ oxidation activity of E28Q becomes clearly visible, revealing a potential dependence that differs greatly from native Hyd-1 (Figure 2A). Two distinct catalytic potential regimes are clearly evident: at $\mathrm{pH} 6.0$ the onset of $\mathrm{H}_{2}$ oxidation occurs at approximately $-0.3 \mathrm{~V}$ and a second regime commences at around $+0.05 \mathrm{~V}$. In contrast, native Hyd-1 shows only one potential regime for $\mathrm{H}_{2}$ oxidation, which commences at approximately $-0.3 \mathrm{~V}$, as previously noted in several papers. ${ }^{17,19,20}$ The second catalytic regime seen with $\mathrm{E} 28 \mathrm{Q}$ which results in a 3-fold increase in current at $+0.6 \mathrm{~V}$ relative to that at $+0.05 \mathrm{~V}$, is due to enzymatic $\mathrm{H}_{2}$ oxidation: switching to $100 \% \mathrm{Ar}$ causes the current to drop to background levels (Figure 2B) and returning to $100 \% \mathrm{H}_{2}$ at $\sim+0.3 \mathrm{~V}$ immediately restores the current, which is retained upon subsequent scans. For both enzymes, the return scan to more negative potential shows an activation step, seen as a ridge, which appears at a more positive potential for E28Q.

The experiments were repeated over the $\mathrm{pH}$ range 4-10.8 for native Hyd-1 (Figure 3A) and E28Q (Figure 3B). Measured at $-0.2 \mathrm{~V}$, the $\mathrm{H}_{2}$ oxidation activity of the native enzyme reaches a maximum at $\mathrm{pH} 8$. The decrease in current that occurs as the potential is increased further, and which is most evident at high $\mathrm{pH}$, is generally ascribed to the formation of resting state $\mathrm{Ni}-\mathrm{B}^{33}$ (but see later), which contains a bridging $\mathrm{OH}^{-}$ligand. ${ }^{44,45}$ The $\mathrm{H}_{2}$ oxidation activity of E28Q shows a completely different trend with $\mathrm{pH}$, particularly as the activity measured at $-0.2 \mathrm{~V}$ increases with $\mathrm{pH}$, accelerating sharply above $\mathrm{pH} 9$ (Figure 3B,C and Figure S4). Like native Hyd-1, the E28Q variant only becomes a reversible catalyst at low $\left[\mathrm{H}_{2}\right]$ and low $\mathrm{pH}^{20,46,47}$ (Figure $\mathrm{S} 4$ and Figure S5), although the $\mathrm{H}^{+}$reduction rate must be extremely low.

To investigate the origin of this shift in $\mathrm{pH}$ dependence of maximal $\mathrm{H}_{2}$ oxidation activity, the Hyd-1 E28D variant was made (Table S1). The mutation retains the carboxylate functionality but shortens the side chain by one carbon atom. Protein film voltammetry of E28D revealed only one 


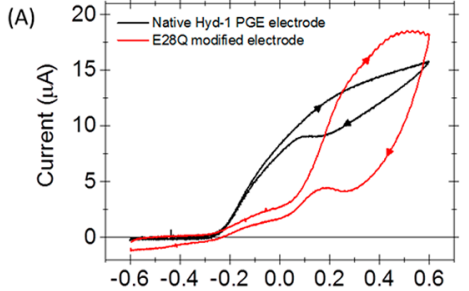

(B)

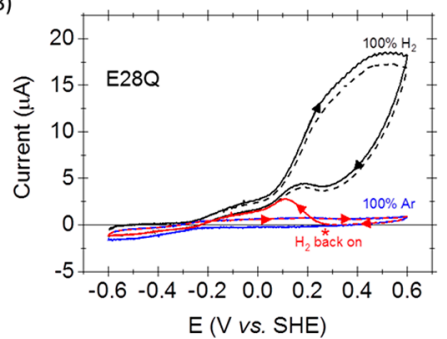

Figure 2. Using a modified electrode, activated E28Q displays a significant current, with two distinct potential regimes compared to native Hyd-1 (A), both of which can be attributed to enzymatic $\mathrm{H}_{2}$ oxidation (B); A direct comparison is shown of the voltammetric response of native Hyd-1 (black trace, A) and E28Q (red trace, A) scanned at $5 \mathrm{mV} / \mathrm{s}$ between -0.6 and $+0.6 \mathrm{~V}$ in $100 \% \mathrm{H}_{2}$ (arrows indicate scan direction). The native Hyd-1 film was produced using a standard PGE electrode and the E28Q data were measured using a modified electrode, i.e., the absolute currents do not represent turnover rate as coverage is not accounted for. Other conditions: $\mathrm{pH}$ $6.0,37^{\circ} \mathrm{C}$, total gas flow rate maintained at $1000 \mathrm{scc} / \mathrm{min}, \omega=1000-$ $3000 \mathrm{rpm}$. The two potential regimes of E28Q report on hydrogen oxidation where the potential was cycled between -0.6 and $+0.6 \mathrm{~V}$ at $5 \mathrm{mV} / \mathrm{s}$ in $100 \% \mathrm{H}_{2}$ (black, B), the gas headspace was then changed to $100 \% \mathrm{Ar}$ (blue, B) for 3 full potential cycles to ensure gas equilibration was complete. On the subsequent scan to low potential, at $\sim+0.3 \mathrm{~V}$ (red, (B) denoted by *) the $\mathrm{H}_{2}$ flow into the headspace was turned back on. The following scan in $100 \% \mathrm{H}_{2}$ shows the current approaching that of the initial scan (dashed black line, B). Arrows indicate the direction of the potential sweep. Other conditions: total gas flow rate maintained at $1000 \mathrm{scc} / \mathrm{min}, \mathrm{pH} 6.0,37^{\circ} \mathrm{C}, \omega=1000$ rpm.

potential regime and a $\mathrm{pH}$ dependence similar to native Hyd-1 and in contrast to E28Q (Figure S6).

3.3. Steady-State $\mathrm{H}_{2}$ Oxidation Rates of E28 Variants Measured by PFE and Solution Assays. Figure 4 compares the steady-state $\mathrm{H}_{2}$ oxidation activities of native $\mathrm{Hyd}-1$ and E28Q across a wide $\mathrm{pH}$ range ( $\mathrm{pH}$ 6-12), as measured by PFE (at $-0.2 \mathrm{~V}$, Figure $4 \mathrm{~A}$ ) and solution assays (Figure $4 \mathrm{~B}$ and Table S2). The maximal activity at $-0.2 \mathrm{~V}$ for native Hyd-1 occurs at $\mathrm{pH} 8$, whereas for E28Q it continues to rise up to at least $\mathrm{pH} 10.5$, above which the current becomes very unstable, as shown in Figure 3C which includes experiments conducted up to $\mathrm{pH}$ 12. The general $\mathrm{pH}$ trend of activities for both enzymes as measured by PFE agrees very well with the steadystate solution assay rates. The E28Q variant is an extremely poor catalyst at $\mathrm{pH} 6$, with a nominal activity $\left(1.5 \pm 0.1 \mathrm{~s}^{-1}\right)$ of just $0.6 \%$ that of native Hyd-1 $\left(253 \pm 27 \mathrm{~s}^{-1}\right)$. The activity at $\mathrm{pH} 10.8$ increases $\left(\sim 10 \mathrm{~s}^{-1}\right)$ to approximately that of native Hyd-1 $\left(\sim 13 \mathrm{~s}^{-1}\right)$ measured under the same conditions. The E28D variant has approximately $40 \%$ of the native Hyd-1 activity at pH $6\left(109 \pm 9 \mathrm{~s}^{-1}\right.$, or $63 \pm 5 \mu \mathrm{mol} \mathrm{H}_{2} \mathrm{~min}^{-1} \mathrm{mg}^{-1}$ of enzyme), a similar attenuation of activity as previously reported for the equivalent variant in D. fructosovorans. ${ }^{24}$

From PFE experiments (and PFIRE, see later) it was clear that Hyd-1 variants incorporating the E28Q change are
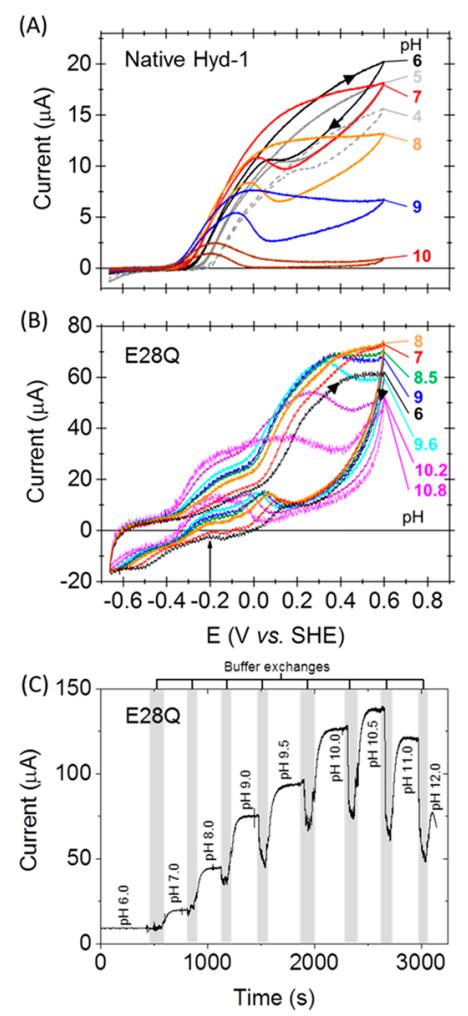

Figure 3. $\mathrm{pH}$ dependence of $\mathrm{H}_{2}$ oxidation activity for native Hyd-1 and E28Q. For native Hyd-1 (A) using a standard PGE electrode, the potential was scanned at $5 \mathrm{mV} / \mathrm{s}$ between -0.65 and $+0.6 \mathrm{~V}$ in $100 \%$ $\mathrm{H}_{2}$ (for clarity, the scan direction is indicated with arrows on the $\mathrm{pH} 6$ scan, black). The film was exposed to the mixed buffer system at each $\mathrm{pH}$ in the order 6, 4, 5, 7, 8, 9, 10. For E28Q (B) using a modified electrode, the potential was scanned at $5 \mathrm{mV} / \mathrm{s}$ between -0.659 and $+0.6 \mathrm{~V}$ in $100 \% \mathrm{H}_{2}$ (for clarity, the scan direction is indicated with arrows on the $\mathrm{pH} 6$ scan, black). The film was exposed to a potassium phosphate $(100 \mathrm{mM}), \mathrm{NaCl}(100 \mathrm{mM})$ buffer at each $\mathrm{pH}$ in the order $6,7,8,8.5,9,9.6,10.2,10.8$. For both native Hyd-1 and E28Q, the buffer was returned to $\mathrm{pH} 6$ in between each $\mathrm{pH}$ to enable film loss correction. Each buffer was pre-equilibrated with $100 \% \mathrm{H}_{2}$, and 2 scans were taken at each $\mathrm{pH}$ to ensure complete gas and temperature equilibration. For E28Q the black vertical arrow emphasizes the increase in current with increasing $\mathrm{pH}$, seen at all $\mathrm{pH}$ values below $\sim 0$ V. Other conditions: $37{ }^{\circ} \mathrm{C}$, total gas flow rate maintained at 1000 $\mathrm{scc} / \mathrm{min}, \omega=2500 \mathrm{rpm}$. For E28Q (C) using a modified electrode, a buffer titration was performed during a chronoamperometry experiment at $-0.2 \mathrm{~V}$ in $100 \% \mathrm{H}_{2}$. Starting at $\mathrm{pH} 6.0$, the current was allowed to reach a plateau and the buffer then exchanged for increasingly high $\mathrm{pH}$ values while maintaining the electrical connection to the cell (gray areas). Immediately following the buffer exchange there is an increase in current due to temperature and gas equilibration of the new buffer. The current was allowed to stabilize before the next buffer exchange was initiated. A potassium phosphate $(100 \mathrm{mM}), \mathrm{NaCl}(100 \mathrm{mM})$ buffer was used throughout. Other conditions: $37^{\circ} \mathrm{C}$, total gas flow rate maintained at $1000 \mathrm{scc} / \mathrm{min}, \omega=$ $1000 \mathrm{rpm}$.

extremely difficult to activate (days not hours). Because reduction of oxidized inactive states $\mathrm{Ni}-\mathrm{B}$ and $\mathrm{Ni}-\mathrm{A}$ (and other unready states ${ }^{44}$ ) requires protons as well as electrons, this observation was not surprising, but it served to emphasize the need for exhaustive activation of as-isolated enzymes.

3.4. Additional Variants to Investigate the Involvement of the Proximal Fe-S Cluster. We considered it certain that the high-potential activity commencing above 
(A) PFE activity

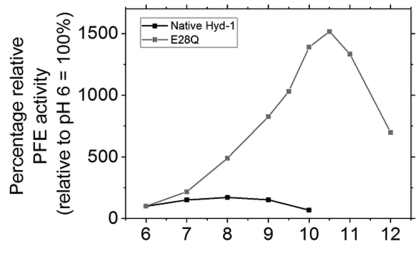

$\mathrm{pH}$
(B) Steady-state solution assay

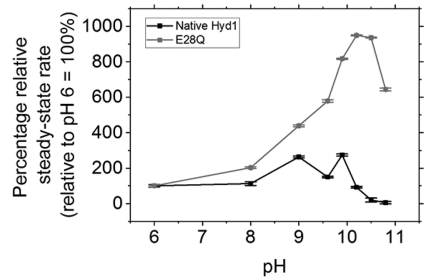

Figure 4. $\mathrm{pH}$ dependence of percentage activities of native Hyd- 1 and E28Q based on PFE current at $-0.2 \mathrm{~V}$ at $37^{\circ} \mathrm{C}$ (A) and the steadystate $\mathrm{H}_{2}$ oxidation solution assay rates of native Hyd-1 and E28Q at $25{ }^{\circ} \mathrm{C}(\mathrm{B})$. For PFE data, the average current was taken at $-0.2 \mathrm{~V}$ for the forward and reverse scans for native Hyd-1 (Figure 3A) in the $\mathrm{pH}$ range $6-10$, while for E28Q the average current at $-0.2 \mathrm{~V}$ during a chronoamperometry buffer exchange experiment was used at each $\mathrm{pH}$ in the range 6-12 (Figure 3C). The potential of $-0.2 \mathrm{~V}$ was chosen as for native Hyd-1 this is the upper limit for $\mathrm{H}_{2}$ oxidation before inactivation to Ni-B at $\mathrm{pH} 10$. All fractional PFE activity and steadystate rate data are presented as a percentage relative to $\mathrm{pH} 6(\mathrm{pH} 6$ is normalized to $100 \%$ and is $252.8 \pm 27.3 \mathrm{~s}^{-1}$ for native Hyd-1 and 1.5 $\pm 0.1 \mathrm{~s}^{-1}$ for $\mathrm{E} 28 \mathrm{Q}$, see Table S2). For steady-state solution assays, errors represent the propagated standard error of the mean of at least three repeats.

$+0.05 \mathrm{~V}$ at $\mathrm{pH} 6$ for $\mathrm{E} 28 \mathrm{Q}$ must be associated with a change in state of the enzyme linked to oxidation of a redox-active group. Only two site options are available, based on redox transitions previously assigned for the native enzyme at $\mathrm{pH}$ 6; both involve $\mathrm{Fe}-\mathrm{S}$ clusters, either the medial cluster $[3 \mathrm{Fe}-4 \mathrm{~S}]^{1+/ 0}$ $(+0.130 \pm 0.015 \mathrm{~V})$ or the proximal cluster, which can perform two one-electron reactions: $[4 \mathrm{Fe}-3 \mathrm{~S}]^{4+/ 3+}(+0.030 \pm 0.030 \mathrm{~V})$ and $[4 \mathrm{Fe}-3 \mathrm{~S}]^{5+/ 4+}(+0.230 \pm 0.015 \mathrm{~V}){ }^{48}$ All $\mathrm{O}_{2}$-tolerant [NiFe]-hydrogenases (group $1 \mathrm{~d}^{14}$ ) so far studied possess this special proximal cluster, which is coordinated by 6 cysteines. Its special function appears to be to provide an additional electron when $\mathrm{O}_{2}$ attacks, becoming coordinated by a peptide$\mathrm{N}$ ligand in the superoxidized state, in a process that requires a substantial conformational change at the cluster along with local proton transfer. ${ }^{18,22,48-52}$ Because of its high reduction potential and large conformational change requirements, it is unlikely that the superoxidized state is formed during normal $\mathrm{H}_{2}$ catalysis by native Hyd-1. However, the proximal cluster is located just $7.7 \AA$ (nearest atom distance) from E28 (Figure 1A), making it, and specifically a property conferred by the superoxidation transition, the prime candidate for the enhanced activity of E28Q at high-potential. The medial cluster is too far from E28 to make it a reasonable candidate.

In Hyd-2, the proximal $\mathrm{Fe}-\mathrm{S}$ cluster is a standard [4Fe$4 \mathrm{~S}]^{2+/ 1+}$ cubane located $7.9 \AA$ from the equivalent residue E14. Standard $\mathrm{Fe}-\mathrm{S}$ clusters have more negative reduction potentials than the special proximal cluster of $\mathrm{O}_{2}$-tolerant hydrogenases, ${ }^{53}$ transferring only one electron to the active site without substantial conformational change. To investigate the proximal cluster involvement in the high-potential activity of E28Q we made the equivalent variant in Hyd-2 (E14Q), where a substantial conformational change at the cluster would not be expected upon oxidation. ${ }^{21}$

As for E28Q, PFE experiments with Hyd-2 E14Q required use of a modified electrode in order to see a substantial $\mathrm{H}_{2}$ oxidation current. Within the $\mathrm{pH}$ range of $6-8$, it was clear that there is no enhancement of $\mathrm{H}_{2}$ oxidation activity up to $+0.29 \mathrm{~V}$ (Figure 5A) as the voltammograms showed the expected reversible electrocatalysis ${ }^{4}\left(\mathrm{H}^{+}\right.$reduction at low
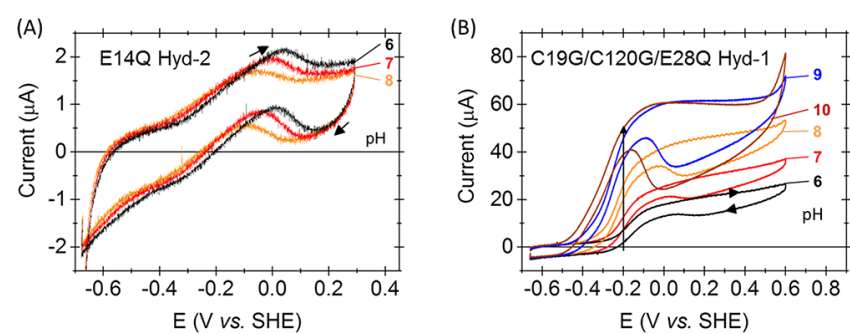

Figure 5. $\mathrm{pH}$ dependence of Hyd-2 variant E14Q (A), where the potential was scanned in $100 \% \mathrm{H}_{2}$ at $1 \mathrm{mV} / \mathrm{s}$ between -0.68 and $+0.29 \mathrm{~V}$ in a mixed buffer system in the order $\mathrm{pH} 8,7,6$. For clarity, arrows indicate the scan direction. A modified electrode was used. Other conditions: $30{ }^{\circ} \mathrm{C}$, total gas flow rate maintained at $1000 \mathrm{scc} /$ min, $\omega=1000 \mathrm{rpm}$. The $\mathrm{pH}$ dependence of the C19G/C120G/E28Q triple Hyd-1 variant (B), where the potential was scanned at $5 \mathrm{mV} / \mathrm{s}$ between -0.66 and $+0.6 \mathrm{~V}$ (arrows are shown for scan direction for the $\mathrm{pH} 6$ scan only, for clarity). The film was exposed to the mixed buffer system at each $\mathrm{pH}$ in the order $7,6,8,9,10$, always returning to $\mathrm{pH} 7$ in between each scan to monitor film loss. Each buffer was preequilibrated with $100 \% \mathrm{H}_{2}$, and 2 scans were taken at each $\mathrm{pH}$ to ensure complete equilibration. The black vertical arrow emphasizes the increase in current with increasing $\mathrm{pH}$ at $-0.2 \mathrm{~V}$. Other conditions: $37^{\circ} \mathrm{C}$, total gas flow rate maintained at $1000 \mathrm{scc} / \mathrm{min}, \omega=$ $2500 \mathrm{rpm}$.

potential) and reversible inactivation at high potential. ${ }^{19}$ Above $\mathrm{pH} \mathrm{8,} \mathrm{E14Q} \mathrm{is} \mathrm{unstable} \mathrm{and} \mathrm{the} \mathrm{resulting} \mathrm{decrease} \mathrm{in} \mathrm{activity}$ ("film loss") restricted further experiments. Oxidation of $\mathrm{H}_{2}$ in steady-state solution assays between $\mathrm{pH}$ 6-9 occurs at a drastically lowered rate ( $>600$-fold at $\mathrm{pH} 6$ ) (Table S3). The $\mathrm{pH}$ dependence of the steady-state turnover rate for E14Q mirrored that of Hyd-1 E28Q increasing with $\mathrm{pH}$ up to $\mathrm{pH} 9$, in contrast to native Hyd-2 which is optimal at $\mathrm{pH} 8.0$ (Figure S7). To investigate the involvement of the proximal cluster without the limitation of protein instability at high $\mathrm{pH}$, we produced a triple C19G/C120G/E28Q variant of Hyd-1 to create a standard cubane proximal cluster incapable of forming the superoxidized state. The plan was based on previous mutagenesis work substituting the supernumerary cysteines of Hyd-1 and Ralstonia eutropha MBH. ${ }^{50,51}$ The triple variant displayed only low activity (noting that the C19G/C120G proximal cluster variant of $\mathrm{Hyd}-1$ previously displayed approximately half the steady-state activity of the native enzyme $^{51}$ ) and again required the use of a modified electrode. Importantly, for all $\mathrm{pH}$ values, there was no evidence of enhancement of activity at high-potential (Figure 5B). These experiments were carried out at rotation rates up to $2500 \mathrm{rpm}$ to exclude $\mathrm{H}_{2}$ mass transport limitations. The current at -0.2 $\mathrm{V}$ increases up to at least $\mathrm{pH} 10$, as previously seen for E28Q (Figure 3B,C).

3.5. Structural Investigations. The PFE data established that replacing the highly conserved glutamate- 28 of Hyd-1 by glutamine does not completely block catalytic proton transfer. Indeed, the enzyme recovers much of its activity under the special conditions of high potential and/or high $\mathrm{pH}$. We thus investigated the structures of Hyd-1 variants at position 28 to identify any differences that might underlie the restoration of activity.

The hydrogenase crystals displayed a long rod-shaped morphology, as previously described, ${ }^{17,21,23}$ and diffraction data could be collected as a helical line scan to spread the radiation dose across the entire volume of the crystal, thus minimizing radiation damage resulting from the photoelectric 


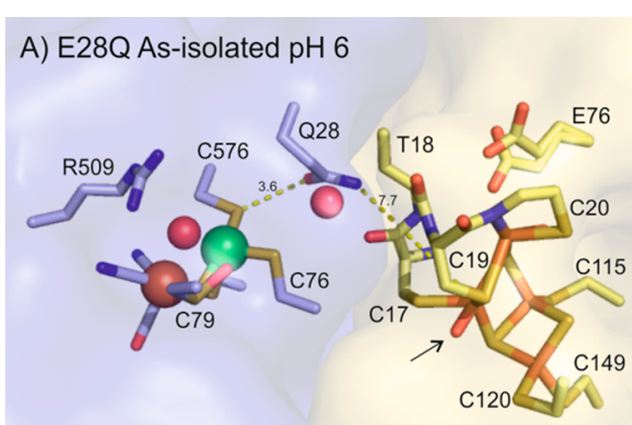

C) $\mathrm{E} 28 \mathrm{Q}$ Reduced $\mathrm{pH} 8$

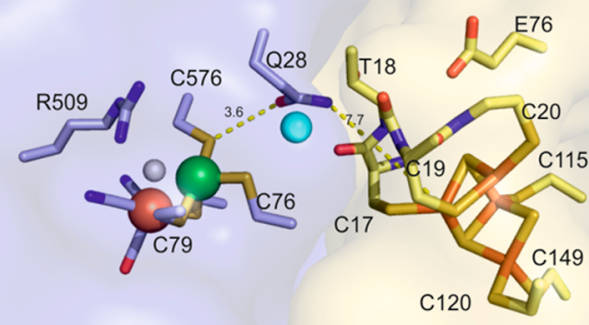

E) Native As-isolated $\mathrm{pH} 8$

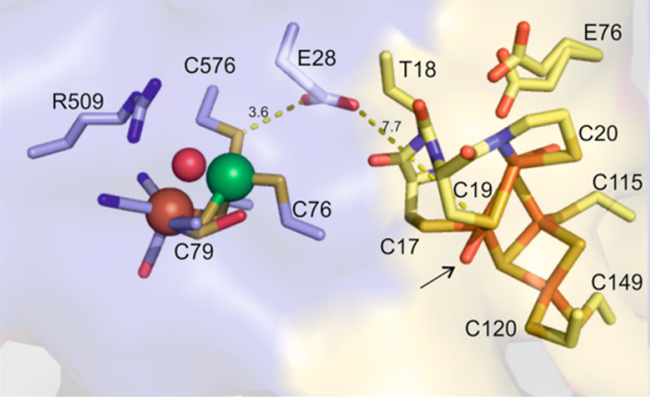

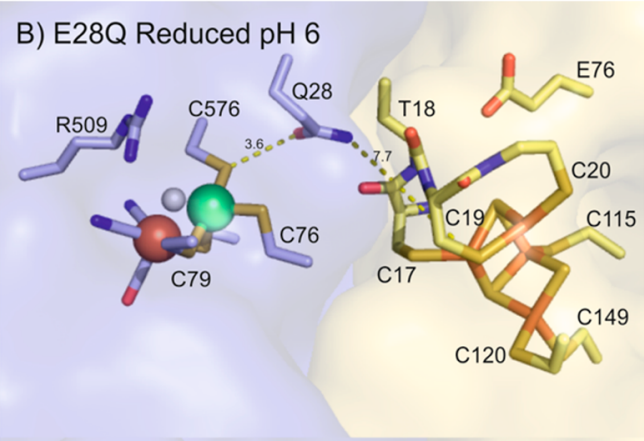

D) E28Q Reduced $\mathrm{pH} 10$

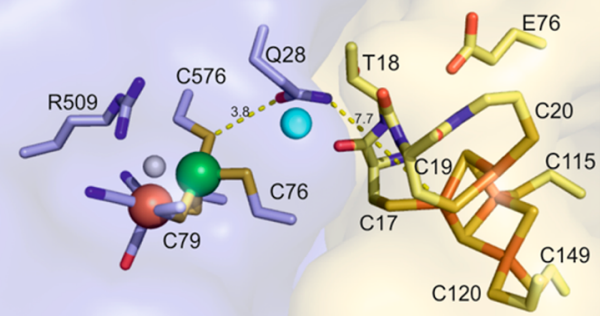

F) Native Reduced pH 6

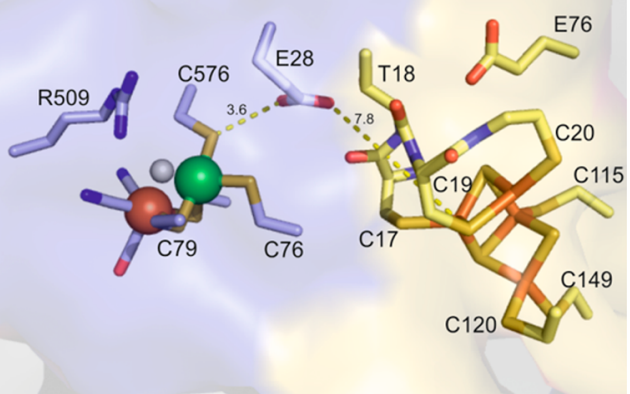

Figure 6. NiFe active site and proximal Fe-S cluster of E28Q (A-D) and Native Hyd-1 (E and F). The interface between the large (blue) and small (yellow) subunits is highlighted by coloring the background for each protein chain. Distances between the functional group of residue 28 and either the $\mathrm{S}$ atom of C576, or the nearest Fe atom of the proximal cluster are given in Angstroms for each structure (dashed lines). The E28Q asisolated (air-oxidized) structure is shown (A) with the hydroxide (red sphere) in the bridging position between $\mathrm{Ni}$ (green sphere) and Fe (orange sphere), and oxygenation at $\mathrm{C} 79$ as expected for the Ni-A state. ${ }^{55}$ Extra $\mathrm{O}$ atom ligation at Fe4 of the proximal cluster is shown (arrow, see also Figure S9). Upon $\mathrm{H}_{2}$ reduction, the low occupancy $\mathrm{H}_{2} \mathrm{O} / \mathrm{OH}^{-}$molecule seen in $\sim 30 \%$ of the crystal lattice near Q28 (shown as red sphere, A) is lost at $\mathrm{pH} 6(\mathrm{~B})$ but electron density is present in the same position (cyan spheres) at $\mathrm{pH} 8\left(\mathrm{C}, 0.44 \mathrm{e} / \AA^{3}\right)$, and at $\mathrm{pH} 10\left(\mathrm{D}, 0.7 \mathrm{e} / \AA^{3}\right)$. The ligand in the bridging position between the $\mathrm{Ni}$ and $\mathrm{Fe}$ is modeled as a hydride (white sphere) in accordance with the $\mathrm{Ni}_{\mathrm{a}}-\mathrm{R}$ form of the enzyme. The oxygenation at C79 is no longer apparent. The numbering that we adopt for the Fe atoms of the proximal cluster in its different oxidation levels follows that used by Volbeda et al. ${ }^{22}$ The proximal cluster is in its reduced pseudocubane state with no apparent oxidation of the Fe atoms. The conformational heterogeneity of E76 has also been removed upon reduction. The same structural features are seen with the Native enzyme in its asisolated state (E) with the exception of the extra water molecule and rotational heterogeneity of residue 28 (see text). Upon reduction, the native structure (F) again shows a similar loss of the typical features of oxygenation as detailed for E28Q.

effect. All crystals diffracted to high resolution (1.05-1.6 ̊). Tables S4-S6 show the X-ray data collection and refinement statistics for each structure, namely, E28Q oxidized (asisolated, Figure 6A) and reduced under $\mathrm{H}_{2}$ at $\mathrm{pH} 6$ (Figure 6B), pH 8 (Figure 6C), and pH 10 (Figure 6D), native Hyd-1 oxidized (as-isolated, Figure 6E) and reduced under $\mathrm{H}_{2}$ (Figure 6F), E28D oxidized (as-isolated, Figure S11), and E14Q (as isolated and $\mathrm{H}_{2}$ reduced Figures 7 and S13).

Structure of E28Q (oxidized, as-isolated). A comparison of the orientation of the Q28 side chain in the oxidized form of E28Q (at pH 6, Figure 6A) relative to native Hyd-1 (at pH 8, Figure $6 \mathrm{E}$ ), suggests a partial disorder of Q28 by rotation about the $\mathrm{C} \alpha-\mathrm{C} \beta$ bond: the $2 \mathrm{Fo}-\mathrm{Fc}$ density for the $\mathrm{C} \gamma, \mathrm{C} \delta$,
$\mathrm{N} \varepsilon$ and $\mathrm{O} \varepsilon$ atoms is $70 \%$ that of $\mathrm{C} \alpha$ and $\mathrm{C} \beta$. An $\mathrm{O}$ atom, either $\mathrm{H}_{2} \mathrm{O}$ or $\mathrm{OH}^{-}$, is seen very close to the amide headgroup with approximately $30 \%$ occupancy (peak height of $1 \mathrm{e} / \AA^{3}$ ). The proximal cluster is in the superoxidized state, characterized by $\mathrm{Fe} 7$ swinging away from the cluster core and coordinating the backbone peptide- $\mathrm{N}$ of $\mathrm{C} 20$ (Fe7 is separated from $\mathrm{N}$ by $2.1 \AA) .{ }^{22}$ Appearance of the superoxidized state of the proximal cluster in the structure is consistent with data from recent EPR spectroscopic experiments. ${ }^{26}$ Nearby carboxylate-bearing residue E76 adopts two conformations, as previously described: ${ }^{22}$ in approximately half the molecules in the crystal lattice, the side chain has rotated to position its carboxylate-O atom $2.15 \AA$ from Fe7. Two of the Fe atoms of 


\section{A E14Q As-isolated $\mathrm{pH} 6$}

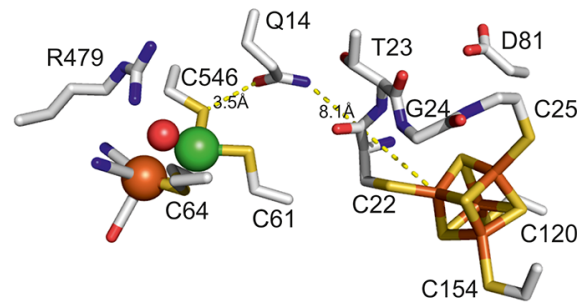

B E14Q Reduced pH 6

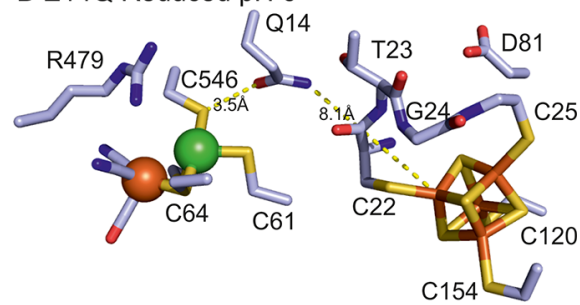

Figure 7. NiFe active site and proximal Fe-S cluster of Hyd-2 E14Q in the as-isolated (air-oxidized) form (A, silver) and $\mathrm{H}_{2}$-reduced form (B, blue). There is minimal change to the active site and proximal cluster upon substitution of glutamate for glutamine, or upon reduction (for an overlay see Figure S13). There is no electron density near the amide headgroup of Q14, i.e., in the position occupied by a $\mathrm{H}_{2} \mathrm{O} / \mathrm{OH}^{-}$in $\mathrm{E} 28 \mathrm{Q}$ (see text). There is no evidence of the oxidation at the proximal cluster that was previously seen for native Hyd-2. ${ }^{21}$

the proximal cluster ( $\mathrm{Fe} 4$ and $\mathrm{Fe} 7)$ appear to have additional ligation (Figures S8A and S9), and we note that an O-ligand at $\mathrm{Fe} 4$ has previously been observed in the $\mathrm{MBH}$ from Ralstonia eutropha. ${ }^{54}$ There is minimal change at the NiFe active site, which can be superposed on that of as-isolated native Hyd-1 with an RMSD of $0.11 \AA$ (Figure 6A,E, and Figure S8A). Bridging ligand C79 is $40 \%$ oxygenated ( $50 \%$ for the native enzyme) and a hydroxide occupies the bridging position between the $\mathrm{Ni}$ and $\mathrm{Fe}$ atoms: both features have previously been seen in as-isolated native Hyd- $1^{17}$ and in hydrogenases from Desulfovibrio fructosovorans and Allochromatium vinosum. ${ }^{55}$

Structure of E28Q ( $\mathrm{H}_{2}$ reduced). In the $\mathrm{H}_{2}$-reduced state, at all $\mathrm{pH}$ values studied, the disorder observed in the Q28 side chain for a subpopulation of the as-isolated enzyme no longer appears (Figure 6B-D and Figure S8B). At $\mathrm{pH} \mathrm{6,} \mathrm{the} \mathrm{low-}$ occupancy $\mathrm{H}_{2} \mathrm{O} / \mathrm{OH}^{-}$molecule close to Q28 is no longer present; however, at $\mathrm{pH} 8$ and $\mathrm{pH} 10$ electron density peaks with heights 0.44 and $0.7 \mathrm{e} / \AA^{3}$ respectively, appear in the same position as the $\mathrm{H}_{2} \mathrm{O} / \mathrm{OH}^{-}$molecule in the as-isolated, oxidized enzyme. The distance between the side chain of Q28 and the $\mathrm{NiFe}$ center also increases slightly at $\mathrm{pH} 10$. Additionally, an ordered CAPS molecule is observed at the surface of the large subunit (chain M) adjacent to residues 184-189. The proximal cluster and surrounding residues undergo the expected $^{18,22,52}$ conformational changes upon reduction at all $\mathrm{pH}$ values, as also seen for native Hyd-1 (Figure 6F, and Figure S8B): $\mathrm{Fe} 7$ has moved back toward the body of the $[4 \mathrm{Fe}-3 \mathrm{~S}]$ cluster to form a pseudocubane structure and the bond between the peptide- $\mathrm{N}$ and the Fe atom, characteristic of the superoxidized state, is no longer present. The side chain heterogeneity of residue E76 is removed (Figure S8) and the oxygen-containing ligands to $\mathrm{Fe} 4$ and $\mathrm{Fe} 7$ (Figure S9) are no longer present. At the active site of $\mathrm{E} 28 \mathrm{Q}$ the distance between the $\mathrm{Ni}$ and $\mathrm{Fe}$ atoms has shortened from 2.98 to 2.66
$\AA$ (as observed previously ${ }^{56}$ ) causing terminal cysteines, C76 and $\mathrm{C} 576$, to rotate approximately $10^{\circ}$ toward the $\mathrm{Ni}$ atom, dragging the polypeptide backbone toward the metal atoms and slightly decreasing the volume of the active site cavity. As a result the amide headgroup of Q28 moves $0.4 \AA$ closer to the $\mathrm{NiFe}$ center, (coordinate uncertainty is 0.07 and $0.03 \AA$ for asisolated and reduced structures respectively). ${ }^{57}$ The electron density ascribed to the bridging $\mathrm{OH}^{-}$species in the as-isolated structure is removed upon reduction; however, a peak (0.94 e/ $\AA^{3}$ ) in the $F_{0}-F_{c}$ map is clearly visible close to and between the metal centers, located $1.6 \AA$ from the $\mathrm{Ni}$ and $1.7 \AA$ from the Fe atom (Figure S10). The coordination distances of the $\mathrm{Ni}$ and $\mathrm{Fe}$ atoms to the center of this peak are typical of a hydride ion and superposition of the active site of the $\mathrm{Ni}_{\mathrm{a}}-\mathrm{R}$ form of $D$. vulgaris Myazaki $\mathrm{F}^{58}$ places the associated hydride in the residual density. Interestingly, bound molecular hydrogen (i.e., the Michaelis complex) may also contribute to the density at the bridging position since the variant has been crystallized at $\mathrm{pH} 5.9$ where turnover is slow: the equivalent variant in $D$. fructosovorans has been shown to be capable of para/ortho hydrogen conversion, but not proton exchange with solvent. ${ }^{24}$

Structure of E28D (oxidized, as-isolated). The as-isolated active site of E28D is unaffected in terms of the positions of the metal coordinating cysteines and residues in the canopy; there is a hydroxide ligand in the bridging position and C576 shows signs of significant oxygenation (Figure S11). ${ }^{17}$ Due to changes in the hydrogen bonding network formed by the truncated side chain of aspartate (relative to glutamate/ glutamine), the polypeptide backbone comprising residues I27, D28 and G29 moves away from the active site relative to E28Q (Figure S12), further demonstrating the flexibility of the polypeptide backbone around residue 28 (see above). The truncation of the side chain also allows an additional $\mathrm{H}_{2} \mathrm{O}$ / $\mathrm{OH}^{-}$molecule to enter the active site cavity: the $\mathrm{H}_{2} \mathrm{O} / \mathrm{OH}^{-}$ occupies the same position as that described above for E28Q in the oxidized, as-isolated state. The proximal cluster of E28D is in the superoxidized conformation. Again an additional $\mathrm{H}_{2} \mathrm{O} / \mathrm{OH}^{-}$ligand bound to $\mathrm{Fe} 4$ is observed and residue E76 adopts two, equally populated conformations allowing interaction with the mobile $\mathrm{Fe} 7$ atom. ${ }^{22}$

Structure of Hyd-2 Variant E14Q, Oxidized (as-isolated) and $\mathrm{H}_{2}$ Reduced. The structures of the active site, proximal cluster and side chain of residue 14 in the Hyd-2 E14Q variant are unchanged relative to the native structure ${ }^{19}$ in both the asisolated and reduced forms at $\mathrm{pH} 6$ (Figure 7 and Figure S13). The proximal cluster is a standard cubane $\mathrm{Fe}-\mathrm{S}$ cluster incapable of forming a superoxidized state. The side chain of Q14 shows no evidence of conformational heterogeneity and there is no electron density corresponding to a $\mathrm{H}_{2} \mathrm{O} / \mathrm{OH}^{-}$ close to the amide headgroup.

Together, the structural results show there is flexibility in the region of residue 28 of Hyd-1, both E28Q and E28D exhibit a superoxidized state of the proximal cluster, and conversion of E28 to an aspartate allows a $\mathrm{H}_{2} \mathrm{O} / \mathrm{OH}^{-}$molecule to enter with $100 \%$ occupancy. Uptake of an analogous $\mathrm{H}_{2} \mathrm{O} / \mathrm{OH}^{-}$molecule close to the amide group of E28Q is only partial, but coincides with superoxidation of the proximal cluster and increased flexibility of residue 28. Moreover, at high $\mathrm{pH}(\mathrm{pH} 8$ and $\mathrm{pH}$ 10), an $\mathrm{H}_{2} \mathrm{O} / \mathrm{OH}^{-}$molecule appears to an increasing degree, even when the proximal cluster is reduced. The inability of Hyd-2 to form an equivalent superoxidized state appears to prevent uptake of $\mathrm{H}_{2} \mathrm{O} / \mathrm{OH}^{-}$, at least at $\mathrm{pH} 6$. 
3.6. Steady-State Protein Film Infrared Electrochemistry of E28Q. The aim of the PFIRE experiments was to identify catalytic intermediates (Figure 1B) for which steady-state levels are elevated or suppressed during turnover as a result of severely restricting proton transfer(s) out of the active site. By this means it was hoped to determine which steps depend on E28 for providing a proton escape route during catalytic $\mathrm{H}_{2}$ oxidation.

The importance of thorough activation of E28Q has been highlighted previously for PFE experiments, and was also noted for analogous PFIRE measurements: use of a partially activated E28Q electrode revealed a much larger population of states at the $\mathrm{Ni}_{\mathrm{a}}$-SI redox level, presumably both active and inactive (not shown).

Measurements were carried out at $\mathrm{pH}$ 7.0, under alternating $100 \% \mathrm{H}_{2}$ and $100 \% \mathrm{Ar}$ atmospheres over a range of applied potentials (Figure S14). A voltammogram recorded in the spectroelectrochemical cell immediately prior to PFIRE measurements confirmed that the electrochemical response of the protein on the carbon black electrode was similar to that recorded on a MWNT modified electrode using PFE (compare Figure 3B and Figure S15).

The difference spectrum obtained by comparing spectra at +356 and $-600 \mathrm{mV}$ under $\mathrm{Ar}$ (Figure $8 \mathrm{~A}$ ) is qualitatively similar to that measured for native Hyd-1 at $\mathrm{pH} 7 .^{59}$ Electrochemical reduction results in complete conversion of the oxidized, inactive, $\mathrm{Ni}-\mathrm{B}$ state (positive peak) and $\mathrm{Ni}_{\mathrm{a}}-\mathrm{R}$ becomes the majority species at $-600 \mathrm{mV}$ (negative peak). A small amount of $\mathrm{Ni}_{\mathrm{a}}-\mathrm{C}$ is evident at $-600 \mathrm{mV}$, but any $\mathrm{Ni}_{\mathrm{a}}-\mathrm{L}$ that might be formed is difficult to identify with certainty above the background (it is worth mentioning that native Hyd1 is unusual in that $\mathrm{Ni}_{\mathrm{a}}-\mathrm{L}$ is observed to a much greater degree than $\mathrm{Ni}_{\mathrm{a}}-\mathrm{C}$ at $\mathrm{pH} 7^{59}$ ). At $+356 \mathrm{mV}$ under $\mathrm{Ar}$, a small amount of an additional species is observed with $v_{\mathrm{CO}}$ close to 1900 $\mathrm{cm}^{-1}$, similar to that reported for other $[\mathrm{NiFe}]$-hydrogenases in oxidized states. ${ }^{55,60}$

As shown in Figure S16, the active site speciation of E28Q at equilibrium under $\mathrm{Ar}$ as a function of potential resembles that of native Hyd-1: ${ }^{33}$ under nonturnover conditions, $\mathrm{Ni}_{\mathrm{a}}-\mathrm{SI}$ dominates at $-100 \mathrm{mV}$ (i.e., during the low potential regime, see Figure 3B and Figure S17) and Ni-B appears at $+100 \mathrm{mV}$ (i.e., during the high potential regime, Figure $3 \mathrm{~B}$ and Figure S17). The difference spectra in Figure $8 \mathrm{~B}, \mathrm{C}$ reflect the distribution of active site species at equilibrium under $\mathrm{Ar}$ (positive peaks) and during steady-state $\mathrm{H}_{2}$ oxidation (negative peaks) in both the low (Figure $8 \mathrm{~B},-100 \mathrm{mV}$ ) and the high (Figure $8 \mathrm{C},+100 \mathrm{mV}$ ) potential regimes. Under conditions driving steady-state $\mathrm{H}_{2}$ oxidation, there is surprisingly little difference between the active site speciation in either potential regime: in both cases $\mathrm{Ni}_{\mathrm{a}}-\mathrm{R}$ dominates, with $\mathrm{Ni}_{\mathrm{a}}-\mathrm{C}$ being the only other active species present at an observable level. The prevalence of $\mathrm{Ni}_{\mathrm{a}} \mathrm{-} \mathrm{R}$ during steady-state $\mathrm{H}_{2}$ oxidation, even when the driving force is approximately $0.5 \mathrm{~V}$, is fully consistent with previous PFIRE measurements for native Hyd-1. ${ }^{33}$

For E28Q under equilibrium conditions (Figure $8 \mathrm{~A}$ ) and during steady-state $\mathrm{H}_{2}$ oxidation (Figure $8 \mathrm{~B}-\mathrm{D}$ ), the dominance of $\mathrm{Ni}_{\mathrm{a}}-\mathrm{C}$ over $\mathrm{Ni}_{\mathrm{a}}-\mathrm{L}$ is in stark contrast to the native enzyme, for which the $\mathrm{Ni}_{\mathrm{a}}-\mathrm{L}$ level exceeds that of $\mathrm{Ni}_{\mathrm{a}}-\mathrm{C}$ by an approximately $2: 1$ ratio at $\mathrm{pH} 7 .{ }^{59}$ Only one form of the $\mathrm{Ni}_{\mathrm{a}}-\mathrm{R}$ state, $\mathrm{Ni}_{\mathrm{a}}-\mathrm{R}(\mathrm{III})$, is observed in $\mathrm{E} 28 \mathrm{Q}$ again in contrast to native Hyd-1. The $\mathrm{Ni}_{\mathrm{a}}-\mathrm{R}(\mathrm{I})$ state is not seen for native Hyd1 or $\mathrm{E} 28 \mathrm{Q}{ }^{33,61}$ The disparity of $\mathrm{Ni}_{\mathrm{a}}-\mathrm{R}$ states between the two
(A)

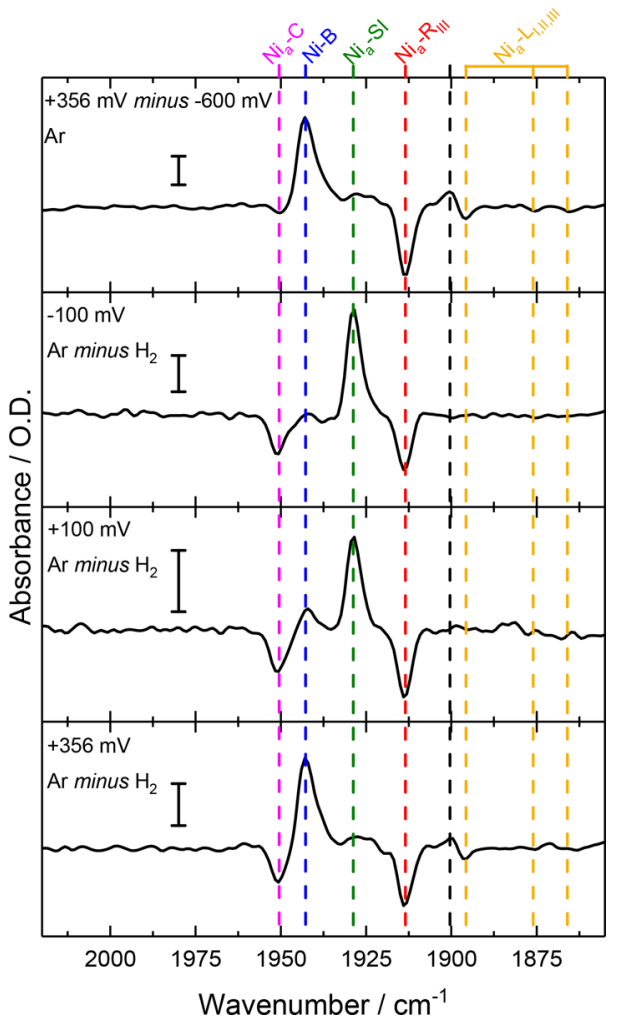

Figure 8. Protein film IR electrochemistry (PFIRE) of E28Q at $\mathrm{pH}$ 7.0, showing the $\nu_{\mathrm{CO}}$ active site spectral region. Data are presented as difference spectra, showing the change in active site speciation as a result of a potential step under an inert Ar atmosphere (A) or in response to steady-state electrocatalytic turnover in the presence of $100 \% \mathrm{H}_{2}$ (B, C and D). Positive bands reflect the equilibrium (nonturnover) behavior of the active site at each potential, and negative bands show states present at low potential (A) or during turnover under $100 \% \mathrm{H}_{2}$. Labeled dashed lines indicate the $\nu_{\mathrm{CO}}$ positions of active site states in native Hyd- $1{ }^{33}$ Black dashed line highlights a small amount of an additional species at $\sim 1900 \mathrm{~cm}^{-1}$ at $+356 \mathrm{mV}$ under $\mathrm{Ar}$ (see text). ${ }^{55,60}$ Scale bars represent 0.1 mO.D. Other details: experiments carried out at $27^{\circ} \mathrm{C} ; \mathrm{H}_{2}$-saturated solution, flow rate of $50 \mathrm{~mL} / \mathrm{min}$ through the PFIRE cell, such that the electrocatalytic current was maximal and independent of flow rate; gas exchange carried out in situ at each potential; linear baseline correction applied between 2150 and $1850 \mathrm{~cm}^{-1}$. The accompanying current-time trace is shown in Figure S14, and the complete difference spectra including the $\nu_{\mathrm{CN}}$ region are shown in Figure S17.

enzymes possibly reflects the role of individual $\mathrm{Ni}_{\mathrm{a}}-\mathrm{R}$ states in sequential proton transfers in the active site during the catalytic cycle. $^{61,62}$

Poising at a potential of $+356 \mathrm{mV}$ under $100 \% \mathrm{H}_{2}$ results in a dramatic loss of catalytic $\mathrm{H}_{2}$ oxidation activity (Figure S14) consistent with the PFE results for E28Q presented earlier. Importantly, the loss of activity does not correlate with Ni-B formation as defined by the IR spectra, and only a small loss of $\mathrm{Ni}_{\mathrm{a}}-\mathrm{SI}$ is observed after inactivation at $+356 \mathrm{mV}$ for $1 \mathrm{~h}$ (Figure S18). This observation contrasts completely with the situation for native $\mathrm{Hyd}-1,{ }^{33}$ where under $\mathrm{H}_{2} \mathrm{Ni}_{\mathrm{a}}$-SI is observable at -70 $\mathrm{mV}$ and undergoes significant conversion of to Ni-B even after a short poise at $+356 \mathrm{mV}$. For $\mathrm{E} 28 \mathrm{Q}$, the $\mathrm{Ni}-\mathrm{B}$ signal is obtained only after replacing the $\mathrm{H}_{2}$ atmosphere with $\mathrm{Ar}$ (Figure 8D) whereupon all remaining activity is lost (Figure S14). 


\section{DISCUSSION AND CONCLUSIONS}

The well-documented role of residue E28 (or its equivalent) in transferring protons in and out of the active site of [NiFe]hydrogenases has so far remained unchallenged. ${ }^{24,26-28}$ For Hyd-1 it is very significant that the activity of E28Q at neutral $\mathrm{pH}$ is not zero, but is of sufficient magnitude to allow spectroscopic measurements that reveal the speciation under conditions of steady-state catalysis. Were a variant to be completely inactive, no such information could be obtained. On the other hand, a variant which retains high activity cannot yield clearly interpretable results. The activity of E28Q at neutral $\mathrm{pH}$ is established to be a "base-level" condition that is relaxed upon increasing the $\mathrm{pH}$ or the electrode potential. Our ability to measure activity and catalytic speciation in a variant for which an essential route for proton transfer out of the active site has now been crystallographically defined over a range of conditions has important consequences for understanding the mechanism of steady-state $\mathrm{H}_{2}$ oxidation. These results and their significance are now discussed.

4.1. Case for the Active Site Being a Near-Perfectly Encapsulated System. At $\mathrm{pH} 6, \mathrm{H}_{2}$ oxidation catalysis by E28Q is so slow that the active site of Hyd-1 can be considered to be encapsulated with regard to a key proton-transfer event during catalysis: E28 offers an essential route for proton exchange with the external environment, without which there is only a low background turnover rate (approximately 1\%, Table S2). Activities reported for the equivalent variant in other bacterial systems vary considerably, ${ }^{24,27,28}$ making Hyd-1 E28Q an extremely valuable model system for the study of E28 as the proton gate.

Numerous crystallographically ordered waters have been previously noted among the $\mathrm{O}_{2}$-tolerant class of $[\mathrm{NiFe}]$ hydrogenases. ${ }^{17}$ Their positions are highly conserved and they could be involved in specific proton transfers within the active site. If proton transfer in Hyd-1 occurred solely via the carboxylate side chain of E28, the Q28 variant should show zero activity. At low $\mathrm{pH}$ and most negative potential, where activity is minimal, the background rate of $\mathrm{H}_{2}$ oxidation lies in the same range as the rate of water molecule release demanded by the rate constant for $\mathrm{O}_{2}$ reduction by native Hyd-1 (Hyd-1 is a hydrogen oxidase). ${ }^{15}$ It is reasonable to attribute this low background activity to an alternative proton-transfer pathway that uses direct migration of an $\mathrm{H}_{2} \mathrm{O} / \mathrm{OH}^{-}$entity and need not involve residue 28 .

4.2. Unusual Increase in Activity at High $\mathrm{pH}$. The stability of Hyd-1 enzymes at $\mathrm{pH}>8$ is fortunate as it allows considerable $\mathrm{H}_{2}$ oxidation current to be measured at moderate potentials, and for crystal structures to be obtained at high $\mathrm{pH}$. The low rate of $\mathrm{H}_{2}$ oxidation increases with $\mathrm{pH}$ in all variants containing glutamine in position 28, i.e. $\mathrm{E} 28 \mathrm{Q}$ and the triple variant of Hyd-1. Even over a limited $\mathrm{pH}$ range, this effect is also seen in the Hyd-2 E14Q variant. Hence, the barrier to $\mathrm{H}_{2}$ oxidation at moderate potentials depends upon a group that is ionized at high $\mathrm{pH}$. A correlation is made here with the appearance in the E28Q as-isolated crystal structure of an ordered $\mathrm{H}_{2} \mathrm{O} / \mathrm{OH}^{-}$molecule. The replacement of a side chain functional group by a water molecule to function as a proton transfer shuttle is not unprecedented. ${ }^{63,64}$ In the as-isolated structure at $\mathrm{pH} 6$, the ordered $\mathrm{H}_{2} \mathrm{O} / \mathrm{OH}^{-}$has partial occupancy $(\sim 30 \%)$. Moreover, the same entity also appears in the $\mathrm{H}_{2}$-reduced enzyme at $\mathrm{pH} 8$ and 10 , the electron density increasing with $\mathrm{pH}$. Based on the greater availability of hydroxide at high $\mathrm{pH}$ and the principle of conservation of charge, it is likely that the $\mathrm{O}$ atom entity is a hydroxide ion. In such a way, the carboxylate is replaced by an electrostatically equivalent amide-hydroxide pair.

4.3. Unusual Increase in Activity at High Potential. No significant $\mathrm{H}_{2}$ oxidation activity is seen for E28Q at $\mathrm{pH} 6$ until a potential more positive than $0 \mathrm{~V}$ is applied. However, the high potential activity only appears in enzymes where the special proximal cluster (found in all group $1 \mathrm{~d},{ }^{14} \mathrm{O}_{2}$-tolerant $[\mathrm{NiFe}]$-hydrogenases to date $\left.{ }^{14,18,22,48,49,52}\right)$ is present. The C19G/C120G/E28Q triple variant of Hyd-1 represents a similar proximal cluster ligation as found in the E14Q variant of $\mathrm{Hyd}-2,{ }^{50,51}$ which is unable to form the superoxidized state, and both enzymes showed only one potential regime. The potential dependence is therefore associated with increasing availability of the superoxidized state as the potential is raised during the catalytic turnover of E28Q. ${ }^{26,48}$ Notably, the crystal structure of the as-isolated form of $\mathrm{E} 28 \mathrm{Q}$ in which the proximal cluster is in the superoxidized state, shows partial ( $\sim 30 \%)$ occupancy by $\mathrm{OH}^{-}$near residue 28 , even at $\mathrm{pH}$ 6: in contrast, while the as-isolated structure of Hyd-2 E14Q which is incapable of forming a superoxidized state, shows no evidence for any bound $\mathrm{OH}^{-}$.

Under normal physiological conditions, the superoxidized state need not be invoked under steady-state catalysis, and is likely only to be used when $\mathrm{O}_{2}$ attacks. ${ }^{50,51,65,66}$ Oxidation of the proximal $\left[4 \mathrm{Fe}-3 \mathrm{~S}\right.$ ] cluster of $\mathrm{Hyd}-1^{17,22}$ (and other $\mathrm{O}_{2}$ tolerant $[\mathrm{NiFe}]$-hydrogenases $\left.{ }^{18,52}\right)$ to its superoxidized state incurs major structural changes (Figure 6), in particular cleavage of an $\mathrm{Fe}-\mathrm{S}$ bond, and movement of the $\mathrm{Fe}$ to form an $\mathrm{Fe}-\mathrm{N}$ (peptide) bond. ${ }^{18,22,48,49,52}$ Redox centers performing fast and efficient electron transfers in enzymes tend not to involve any such large structural changes, ${ }^{10,67}$ and the higher reorganization energy required for redox cycling involving the superoxidized state should certainly retard electron flow. ${ }^{66}$ At $\mathrm{pH} 6$, the glutamine side chain becomes more ordered upon proximal cluster reduction, an action that displaces the $\mathrm{OH}^{-}$ ion, suggesting a plasticity of proton-transfer groups: the glutamine side chain only adopts a native-like conformation in $70 \%$ of the molecules when the proximal cluster is superoxidized. In the remaining $30 \%$ the side chain is disordered by rotation about the $\mathrm{C} \alpha-\mathrm{C} \beta$ bond. Rotation of the equivalent aspartate residue about the $\mathrm{C} \alpha-\mathrm{C} \beta$ bond has also been observed in a $\mathrm{T} 18 \mathrm{~V}$ variant of the $\mathrm{O}_{2}$-sensitive [NiFe]hydrogenase from $\mathrm{D}$. fructosovorans but with no addition of $\mathrm{OH}^{-}$near residue $28 .{ }^{68}$ The affinity of $\mathrm{OH}^{-}$for occupying the position near to the amide of Q28 thus depends on two factors: (1) the proximal cluster being in the superoxidized form or, (2) providing a high $\mathrm{pH}$, even when the proximal cluster is reduced.

4.4. Which Catalytic Steps Are Obstructed during $\mathrm{H}_{2}$ Oxidation? A key question we sought to address in this study is: at which stage (or stages) of the catalytic cycle (Figure 1B) is a proton required to leave the active site via E28? Following thorough activation, the PFIRE data show which stages in the catalytic cycle (Figure 1B) are obstructed in the E28Q variant during steady-state oxidation of $\mathrm{H}_{2}(100 \%)$ at $\mathrm{pH} 7$ (a pH at which the activity of E28Q is lowered to approximately $3 \mathrm{~s}^{-1}$ at $0 \mathrm{~V}$, i.e., approximately $1 \%$ of the native value) when the electrochemical driving force is varied across a wide oxidizing region. Notably, in E28Q $\mathrm{Ni}_{\mathrm{a}}-\mathrm{R}$, followed closely by $\mathrm{Ni}_{\mathrm{a}}-\mathrm{C}$, are the dominant species across the whole range of oxidizing 
conditions, even at $+356 \mathrm{mV}$, a potential at which native Hyd1 converts to $\mathrm{Ni}-\mathrm{B} .^{33}$

Starting the catalytic cycle (Figure 1B) at the level at which $\mathrm{H}_{2}$ binds, i.e., $\mathrm{Ni}_{\mathrm{a}}$-SI, our results establish that stages 1 and 2 , the binding and heterolytic cleavage of $\mathrm{H}_{2}$, do not depend on E28, a result first noted by Dementin and co-workers. ${ }^{24}$ We are now in a position to extend those conclusions to formulate a description of the states dominating during steady-state catalytic $\mathrm{H}_{2}$ oxidation and, therefore, the stages that depend on residue E28. Were E28 to be essential for stages 1 and 2 then we would expect to see accumulation of $\mathrm{Ni}_{\mathrm{a}}$-SI as the dominant species. Advancement of the cycle through to $\mathrm{Ni}_{\mathrm{a}}-\mathrm{C}$ also progresses unabated during turnover and hence stage 3 (the earliest stage at which a proton from $\mathrm{H}_{2}$ must exit the active site) is also unlikely to involve E28. Noting that E28 is not close enough to the $\mathrm{Ni}$ and/or $\mathrm{Fe}$ atoms to be a primary base (Figure 1A), these results suggest that the primary base required for deprotonation of $\mathrm{H}_{2}$ does not depend on E28 for proton exit, or else we would expect to see $\mathrm{Ni}_{\mathrm{a}}$-SI as the dominant species and considerably less $\mathrm{Ni}_{\mathrm{a}}-\mathrm{C}$. The $\mathrm{Ni}_{\mathrm{a}}-\mathrm{L}$ state is a catalytic intermediate in Hyd-1, yet is rarely reported for other hydrogenases during turnover. ${ }^{59}$ In native $\mathrm{Hyd}-1$ the $\mathrm{Ni}_{\mathrm{a}}$ $\mathrm{L}$ state dominates at $\mathrm{pH} 7\left(\mathrm{Ni}_{\mathrm{a}}-\mathrm{C}\right.$ speciation is increased in the native enzyme at low $\mathrm{pH}$ ) and this is consistent with the proposal that an electron from the active site must first transfer to the proximal cluster, which due to its high potential will have a high probability of already being in the reduced state. ${ }^{59}$ For E28Q the increased speciation at the level of $\mathrm{Ni}_{\mathrm{a}}-\mathrm{C}$ (which is observed almost to the exclusion of $\mathrm{Ni}_{\mathrm{a}}-\mathrm{L}$ ) suggests that E28 assists in allowing the hydride to migrate as a proton from the NiFe site in stage 4, consistent with the work of Greene et al.: in the glutamine variant of the soluble hydrogenase I (SHI) from Pyrococcus furiosus, the glutamate proton gate was implicated in the transition from $\mathrm{Ni}_{\mathrm{a}}-\mathrm{C}$ to $\mathrm{Ni}_{\mathrm{a}}-\mathrm{SI}$, with formation of the $\mathrm{Ni}_{\mathrm{a}}-\mathrm{L}$ state only achieved upon photolysis of the bound hydride of $\mathrm{Ni}_{\mathrm{a}}-\mathrm{C} .{ }^{27}$ On the basis of our work with Hyd-1 under turnover conditions, we can now conclude that residue E28 is not essential for activation of $\mathrm{H}_{2}$ from the level of $\mathrm{Ni}_{\mathrm{a}}$-SI to form the $\mathrm{Ni}_{\mathrm{a}}-\mathrm{C}$ state, but is essential for the progression of $\mathrm{H}_{2}$ oxidation beyond the $\mathrm{Ni}_{\mathrm{a}}-\mathrm{C}$ state. It may be significant that the persistent appearance of electron density in the bridging position in reduced structures of E28Q that we tentatively attribute to a hydride based on the work by Ogata et al., ${ }^{58}$ reflects the accumulation of both the $\mathrm{Ni}_{\mathrm{a}}-\mathrm{R}$ and $\mathrm{Ni}_{\mathrm{a}}-\mathrm{C}$ states that are observed spectroscopically.

The unexpected observation that the oxidized inactive state $\mathrm{Ni}-\mathrm{B}$ is not produced when E28Q is subjected to a high potential in the presence of $\mathrm{H}_{2}$ (Figure S18) is now easily explained: interaction of $\mathrm{H}_{2}$ with the active site is maintained in $\mathrm{E} 28 \mathrm{Q}$ and the early stages of $\mathrm{H}_{2}$ activation easily outpace electrochemical oxidation. Formation of $\mathrm{Ni}-\mathrm{B}$ from $\mathrm{Ni}_{\mathrm{a}}-\mathrm{SI}$ under anaerobic conditions (Figure 1B) involves formation of a $\mathrm{Ni}-\mathrm{OH}$ bond that requires not only the passage of a $\mathrm{H}_{2} \mathrm{O}$ molecule into the active site (assuming $\mathrm{OH}^{-}$does not transfer in directly) but also transfer of a $\mathrm{H}^{+}$followed by oxidation of the Ni. If a proton has to exit the active site via E28, it is much easier to start another cycle by activating $\mathrm{H}_{2}$ and generating $\mathrm{Ni}_{\mathrm{a}}-\mathrm{R}$. This competition is retained even when $\mathrm{H}^{+}$transfer is accelerated as the superoxidized form of the proximal cluster becomes dominant. The switch-off of activity of E28Q at very high potential (Figure S14) that is always observable as the potential is swept in the negative direction (Figure $3 \mathrm{~B}$ ), and is normally attributed to formation of $\mathrm{Ni}-\mathrm{B}$, must therefore have a different origin. A plausible explanation is that catalytic electron transfer from the active site to the $\mathrm{Fe}-\mathrm{S}$ cluster relay is retarded due to the higher reorganization requirements associated with cycling the superoxidized proximal cluster. ${ }^{10,66,67}$ The active site remains at the level of $\mathrm{Ni}_{\mathrm{a}}-\mathrm{C}$ or $\mathrm{Ni}_{\mathrm{a}}-\mathrm{R}$ and turnover is stalled. Upon application of a more negative potential, proton-coupled electron transfer is restored and the active pool of enzyme is re-established (Figure S14).

In summary, the active site of Hyd-1 behaves as a nearperfectly encapsulated system, in and out of which proton transfer is strictly regulated, a key residue being glutamate 28 . During $\mathrm{H}_{2}$ oxidation, experiments with the Q28 variant show that E28 is not required for transferring protons out of the active site between intermediates $\mathrm{Ni}_{\mathrm{a}}-\mathrm{SI}$ and $\mathrm{Ni}_{\mathrm{a}}-\mathrm{C}$. Glutamate 28 provides an essential exit route for the proton that was initially formed as a hydride upon $\mathrm{H}_{2}$ cleavage, i.e., during the latter oxidative part of the catalytic cycle. As a consequence, in E28Q, the $\mathrm{Ni}_{\mathrm{a}}$-SI intermediate does not accumulate during $\mathrm{H}_{2}$ oxidation. The structure of the E28Q variant has been examined in detail, the results establishing the basis by which the substituted glutamine is a poor proton-transfer site at neutral $\mathrm{pH}$. A partial rescue of the proton-transfer pathway is achieved through displacement of the amide headgroup by a hydroxide ion, the occupancy of which increases with $\mathrm{pH}$ or as the electrode potential is raised to favor formation of the unusual superoxidized proximal cluster.

\section{ASSOCIATED CONTENT}

\section{Supporting Information}

The Supporting Information is available free of charge on the ACS Publications website at DOI: 10.1021/jacs.8b04798.

Denaturing electrophoresis; plasmid, strains and primer details; PFIRE film preparation; initial E28Q PFE data; additional supporting PFE of E28Q on modified electrodes; PFE data for E28D variant; steady-state solution assay data; X-ray diffraction collection and crystal structure statistics; additional structural figures; PFIRE cyclic voltammograms, chronoamperometry and IR spectra of E28Q (PDF)

\section{AUTHOR INFORMATION}

\section{Corresponding Authors}

*stephen.carr@rc-harwell.ac.uk

*fraser.armstrong@chem.ox.ac.uk

ORCID ${ }^{\circ}$

Philip A. Ash: 0000-0001-5264-464X

Kylie A. Vincent: 0000-0001-6444-9382

Fraser A. Armstrong: 0000-0001-8041-2491

Notes

The authors declare no competing financial interest.

\section{ACKNOWLEDGMENTS}

This research was supported by the UK Biological and Biotechnology Sciences Research Council (Grants BB/ I022309-1 and BB/L009722/1 to F.A.A.). A studentship for E.J.B. was supported by grants from Global Innovation Initiative and the UK Engineering and Physical Sciences Research Council (EPSRC). F.A.A. is a Royal Society Wolfson Research Merit Award holder. The work of K.A.V. and P.A.A. was supported by EPSRC grant EP/N013514/1. We are grateful to Amelia Brasnett for carrying out initial PFIRE 
experiments on E28Q Hyd-1 during a summer internship. We thank Diamond Light Source for beam-time (proposal mx12346) and staff at beamlines I04-1, I03, and I24 for assistance during X-ray data collection.

\section{REFERENCES}

(1) Olson, J. W.; Maier, R. J. Science 2002, 298 (5599), 1788-1790.

(2) Maier, R. J.; Olczak, A.; Maier, S.; Soni, S.; Gunn, J. Infect. Immun. 2004, 72 (11), 6294-6299.

(3) Woolerton, T. W.; Sheard, S.; Chaudhary, Y. S.; Armstrong, F. A. Energy Environ. Sci. 2012, 5 (6), 7470-7490.

(4) Armstrong, F. A.; Hirst, J. Proc. Natl. Acad. Sci. U. S. A. 2011, 108 (34), 14049-14054.

(5) Boralugodage, N. P.; Arachchige, R. J.; Dutta, A.; Buchko, G. W.; Shaw, W. J. Catal. Sci. Technol. 2017, 7 (5), 1108-1121.

(6) Rakowski DuBois, M.; DuBois, D. L. Chem. Soc. Rev. 2009, 38 (1), 62-72.

(7) Smith, S. E.; Yang, J. Y.; DuBois, D. L.; Bullock, R. M. Angew. Chem., Int. Ed. 2012, 51 (13), 3152-3155.

(8) Vignais, P. M. Coord. Chem. Rev. 2005, 249 (15), 1677-1690.

(9) Klinman, J. P. Trends Biochem. Sci. 1989, 14 (9), 368-373.

(10) Page, C. C.; Moser, C. C.; Chen, X.; Dutton, P. L. Nature 1999, 402, 47-52.

(11) Montet, Y.; Amara, P.; Volbeda, A.; Vernede, X.; Hatchikian, E. C.; Field, M. J.; Frey, M.; Fontecilla-Camps, J. C. Nat. Struct. Biol. 1997, 4 (7), 523-526.

(12) Kalms, J.; Schmidt, A.; Frielingsdorf, S.; van der Linden, P.; von Stetten, D.; Lenz, O.; Carpentier, P.; Scheerer, P. Angew. Chem., Int. Ed. 2016, 55, 5586-5590.

(13) Kalms, J.; Schmidt, A.; Frielingsdorf, S.; Utesch, T.; Gotthard, G.; von Stetten, D.; van der Linden, P.; Royant, A.; Mroginski, M. A.; Carpentier, P.; Lenz, O.; Scheerer, P. Proc. Natl. Acad. Sci. U. S. A. 2018, 115, E2229-E2237.

(14) Greening, C.; Biswas, A.; Carere, C. R.; Jackson, C. J.; Taylor, M. C.; Stott, M. B.; Cook, G. M.; Morales, S. E. ISME J. 2016, 10 (3), 761-777.

(15) Wulff, P.; Day, C. C.; Sargent, F.; Armstrong, F. A. Proc. Natl. Acad. Sci. U. S. A. 2014, 111 (18), 6606-6611.

(16) Lauterbach, L.; Lenz, O. J. Am. Chem. Soc. 2013, 135, 1789717905 .

(17) Evans, R. M.; Brooke, E. J.; Wehlin, S. A. M.; Nomerotskaia, E.; Sargent, F.; Carr, S. B.; Phillips, S. E. V.; Armstrong, F. A. Nat. Chem. Biol. 2016, 12, 46-50.

(18) Fritsch, J.; Scheerer, P.; Frielingsdorf, S.; Kroschinsky, S.; Friedrich, B.; Lenz, O.; Spahn, C. M. T. Nature 2011, 479 (7372), 249-252.

(19) Lukey, M. J.; Parkin, A.; Roessler, M. M.; Murphy, B. J.; Harmer, J.; Palmer, T.; Sargent, F.; Armstrong, F. A. J. Biol. Chem. 2010, 285 (6), 3928-3938.

(20) Murphy, B. J.; Sargent, F.; Armstrong, F. A. Energy Environ. Sci. 2014, 7 (4), 1426-1433.

(21) Beaton, S. E.; Evans, R. M.; Finney, A. J.; Lamont, C. M.; Armstrong, F. A.; Sargent, F.; Carr, S. B. Biochem. J. 2018, 475, 13531370.

(22) Volbeda, A.; Amara, P.; Darnault, C.; Mouesca, J.-M.; Parkin, A.; Roessler, M. M.; Armstrong, F. A.; Fontecilla-Camps, J. C. Proc. Natl. Acad. Sci. U. S. A. 2012, 109 (14), 5305-5310.

(23) Brooke, E. J.; Evans, R. M.; Islam, S. T. A.; Roberts, G. M.; Wehlin, S. A. M.; Carr, S. B.; Phillips, S. E. V.; Armstrong, F. A. Biochemistry 2017, 56, 132-142.

(24) Dementin, S.; Burlat, B.; De Lacey, A. L.; Pardo, A.; Adryanczyk-Perrier, G.; Guigliarelli, B.; Fernandez, V. M.; Rousset, M. J. Biol. Chem. 2004, 279 (11), 10508-10513.

(25) Chen, K.; Hirst, J.; Camba, R.; Bonagura, C. A.; Stout, C. D.; Burgess, B. K.; Armstrong, F. A. Nature 2000, 405 (6788), 814-817.

(26) Adamson, H.; Robinson, M.; Wright, J. J.; Flanagan, L. A.; Walton, J.; Elton, D.; Gavaghan, D. J.; Bond, A. M.; Roessler, M. M.; Parkin, A. J. Am. Chem. Soc. 2017, 139 (31), 10677-10686.
(27) Greene, B. L.; Vansuch, G. E.; Wu, C.-H.; Adams, M. W. W.; Dyer, R. B. J. Am. Chem. Soc. 2016, 138 (39), 13013-13021.

(28) Szőri-Dorogházi, E.; Maróti, G.; Szőri, M.; Nyilasi, A.; Rákhely, G.; Kovács, K. L. PLoS One 2012, 7 (4), No. e34666.

(29) Evans, R. M.; Armstrong, F. A. Electrochemistry of Metalloproteins: Protein Film Electrochemistry for the Study of E. Coli [NiFe]-Hydrogenase-1. In Metalloproteins - Methods and Protocols; Fontecilla-Camps, J. C., Nicolet, Y., Eds.; Humana Press: New York, 2014; pp 73-94.

(30) Armstrong, F. A.; Evans, R. M.; Hexter, S. V.; Murphy, B. J.; Roessler, M. M.; Wulff, P. Acc. Chem. Res. 2016, 49, 884-892.

(31) Rüdiger, O.; Abad, J. M.; Hatchikian, E. C.; Fernandez, V. M.; De Lacey, A. L. J. Am. Chem. Soc. 2005, 127 (46), 16008-16009.

(32) Krishnan, S.; Armstrong, F. A. Chem. Sci. 2012, 3 (4), 10151023.

(33) Hidalgo, R.; Ash, P. A.; Healy, A. J.; Vincent, K. A. Angew. Chem., Int. Ed. 2015, 54, 7110-7113.

(34) Ash, P. A.; Hidalgo, R.; Vincent, K. A. J. Visualized Exp. 2017, 130, No. e55858, DOI: $10.3791 / 55858$.

(35) Arp, D. J.; Burris, R. H. Biochemistry 1981, 20 (8), 2234-2240.

(36) Cammack, R.; Fernandez, V. M.; Claude Hatchikian, E.; Harry, D.; Peck, J. J. L. [5] Nickel-Iron Hydrogenase. In Methods in Enzymology; Academic Press: New York, 1994; Vol. 243, pp 43-68.

(37) Bard, A. J.; Faulkner, L. R. Electrochemical Methods; Wiley: New York, 2001.

(38) Baffert, C.; Sybirna, K.; Ezanno, P.; Lautier, T.; Hajj, V.; Meynial-Salles, I.; Soucaille, P.; Bottin, H.; Léger, C. Anal. Chem. 2012, 84 (18), 7999-8005.

(39) Alonso-Lomillo, M. A.; Rüdiger, O.; Maroto-Valiente, A.; Velez, M.; Rodríguez-Ramos, I.; Muñoz, F. J.; Fernández, V. M.; De Lacey, A. L. Nano Lett. 2007, 7 (6), 1603-1608.

(40) Waterman, D. G.; Winter, G.; Parkhurst, J. M.; FuentesMontero, L.; Hattne, J.; Brewster, A.; Sauter, N. K.; Evans, G. CCP4 Newsl. Protein Crystallogr. 2013, 49, 16-19.

(41) Evans, P. R. Acta Crystallogr., Sect. D: Biol. Crystallogr. 2011, 67 (4), 282-292.

(42) Murshudov, G. N.; Skubak, P.; Lebedev, A. A.; Pannu, N. S.; Steiner, R. A.; Nicholls, R. A.; Winn, M. D.; Long, F.; Vagin, A. A. Acta Crystallogr., Sect. D: Biol. Crystallogr. 2011, 67 (4), 355-367.

(43) Emsley, P.; Lohkamp, B.; Scott, W. G.; Cowtan, K. Acta Crystallogr., Sect. D: Biol. Crystallogr. 2010, 66 (4), 486-501.

(44) Lubitz, W.; Ogata, H.; Rüdiger, O.; Reijerse, E. Chem. Rev. 2014, 114 (8), 4081-4148.

(45) Volbeda, A.; Martin, L.; Cavazza, C.; Matho, M.; Faber, B. W.; Roseboom, W.; Albracht, S. P. J.; Garcin, E.; Rousset, M.; FontecillaCamps, J. C. JBIC, J. Biol. Inorg. Chem. 2005, 10 (3), 239-249.

(46) Hexter, S. V.; Grey, F.; Happe, T.; Climent, V.; Armstrong, F. A. Proc. Natl. Acad. Sci. U. S. A. 2012, 109 (29), 11516-11521.

(47) Hexter, S. V.; Esterle, T. F.; Armstrong, F. A. Phys. Chem. Chem. Phys. 2014, 16 (24), 11822.

(48) Roessler, M. M.; Evans, R. M.; Davies, R. A.; Harmer, J.; Armstrong, F. A. J. Am. Chem. Soc. 2012, 134 (37), 15581-15594.

(49) Pandelia, M.-E.; Nitschke, W.; Infossi, P.; Giudici-Orticoni, M.T. M.-T.; Bill, E.; Lubitz, W. Proc. Natl. Acad. Sci. U. S. A. 2011, 108 (15), 6097-6102.

(50) Goris, T.; Wait, A. F.; Saggu, M.; Fritsch, J.; Heidary, N.; Stein, M.; Zebger, I.; Lendzian, F.; Armstrong, F. A.; Friedrich, B.; Lenz, O. Nat. Chem. Biol. 2011, 7, 310-318.

(51) Lukey, M. J.; Roessler, M. M.; Parkin, A.; Evans, R. M.; Davies, R. A.; Lenz, O.; Friedrich, B.; Sargent, F.; Armstrong, F. A. J. Am. Chem. Soc. 2011, 133 (42), 16881-16892.

(52) Shomura, Y.; Yoon, K.-S.; Nishihara, H.; Higuchi, Y. Nature 2011, 479 (7372), 253-256.

(53) Parkin, A.; Sargent, F. Curr. Opin. Chem. Biol. 2012, 16 (1-2), 26-34.

(54) Frielingsdorf, S.; Fritsch, J.; Schmidt, A.; Hammer, M.; Löwenstein, J.; Siebert, E.; Pelmenschikov, V.; Jaenicke, T.; Kalms, J.; Rippers, Y.; Lendzian, F.; Zebger, I.; Teutloff, C.; Kaupp, M.; Bittl, 
R.; Hildebrandt, P.; Friedrich, B.; Lenz, O.; Scheerer, P. Nat. Chem. Biol. 2014, 10, 378-385.

(55) Volbeda, A.; Martin, L.; Barbier, E.; Gutiérrez-Sanz, O.; De Lacey, A. L.; Liebgott, P.-P.; Dementin, S.; Rousset, M.; FontecillaCamps, J. C. JBIC, J. Biol. Inorg. Chem. 2015, 20 (1), 11-22.

(56) Parida, P.; Kundu, A.; Pati, S. K. J. Cluster Sci. 2009, 20 (2), $355-364$.

(57) Cruickshank, D. W. J. Acta Crystallogr., Sect. D: Biol. Crystallogr. 1999, 55 (3), 583-601.

(58) Ogata, H.; Nishikawa, K.; Lubitz, W. Nature 2015, 520, 571574.

(59) Murphy, B. J.; Hidalgo, R.; Roessler, M. M.; Evans, R. M.; Ash, P. A.; Myers, W. K.; Vincent, K. A.; Armstrong, F. A. J. Am. Chem. Soc. 2015, 137, 8484-8489.

(60) Bleijlevens, B.; van Broekhuizen, F. A.; De Lacey, A. L.; Roseboom, W.; Fernandez, V. M.; Albracht, S. P. J. JBIC, J. Biol. Inorg. Chem. 2004, 9, 743-752.

(61) Ash, P. A.; Hidalgo, R.; Vincent, K. A. ACS Catal. 2017, 7 (4), $2471-2485$.

(62) Ash, P. A.; Carr, S. B.; Reeve, H. A.; Skorupskaite, A.; Rowbotham, J. S.; Shutt, R.; Frogley, M. D.; Evans, R. M.; Cinque, G.; Armstrong, F. A.; Vincent, K. A. Chem. Commun. 2017, 53, 58585861.

(63) Pankhurst, K. L.; Mowat, C. G.; Rothery, E. L.; Hudson, J. M.; Jones, A. K.; Miles, C. S.; Walkinshaw, M. D.; Armstrong, F. A.; Reid, G. A.; Chapman, S. K. J. Biol. Chem. 2006, 281 (29), 20589-20597. (64) Mowat, C. G.; Pankhurst, K. L.; Miles, C. S.; Leys, D.; Walkinshaw, M. D.; Reid, G. A.; Chapman, S. K. Biochemistry 2002, 41 (40), 11990-11996.

(65) Evans, R. M.; Parkin, A.; Roessler, M. M.; Murphy, B. J.; Adamson, H.; Lukey, M. J.; Sargent, F.; Volbeda, A.; FontecillaCamps, J. C.; Armstrong, F. A. J. Am. Chem. Soc. 2013, 135 (7), 2694-2707.

(66) Radu, V.; Frielingsdorf, S.; Lenz, O.; Jeuken, L. J. C. Chem. Commun. 2016, 52, 2632-2635.

(67) Sigfridsson, E.; Olsson, M. H. M.; Ryde, U. Inorg. Chem. 2001, 40 (11), 2509-2519.

(68) Abou-Hamdan, A.; Ceccaldi, P.; Lebrette, H.; Gutiérrez-Sanz, O.; Richaud, P.; Cournac, L.; Guigliarelli, B.; De Lacey, A. L.; Léger, C.; Volbeda, A.; Burlat, B.; Dementin, S. J. Biol. Chem. 2015, 290 (13), 8550-8558.

(69) Cracknell, J. A.; Wait, A. F.; Lenz, O.; Friedrich, B.; Armstrong, F. A. Proc. Natl. Acad. Sci. U. S. A. 2009, 106 (49), 20681-20686.

(70) Greene, B. L.; Wu, C.-H.; Vansuch, G. E.; Adams, M. W. W.; Dyer, R. B. Biochemistry 2016, 55 (12), 1813-1825.

(71) Ogata, H.; Krämer, T.; Wang, H.; Schilter, D.; Pelmenschikov, V.; van Gastel, M.; Neese, F.; Rauchfuss, T. B.; Gee, L. B.; Scott, A. D.; Yoda, Y.; Tanaka, Y.; Lubitz, W.; Cramer, S. P. Nat. Commun. 2015, 6, 7890.

(72) Kampa, M.; Pandelia, M.-E.; Lubitz, W.; van Gastel, M.; Neese, F. J. Am. Chem. Soc. 2013, 135 (10), 3915-3925. 